\title{
WATER WITHDRAWALS IN THE BLACK WARRIOR-TOMBIGBEE BASIN AND ALCORN COUNTY, MISSISSIPPI, 1985-87
}

by Nancy L. Barber

\section{U.S. GEOLOGICAL SURVEY}

Water-Resources Investigations Report 90-4061

Prepared in cooperation with the U.S. ARMY CORPS OF ENGINEERS MOBILE DISTRICT

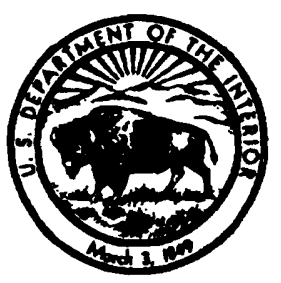

Jackson, Mississippi 1991 


\title{
U.S. DEPARTMENT OF THE INTERIOR \\ MANUEL LUJAN, JR., Secretary
}

\author{
U.S. GEOLOGICAL SURVEY
}

Dallas L. Peck, Director

For additional information write to:

District Chief

U.S. Geological Survey

100 W. Capitol Street

Suite 710, Federal Building

Jackson, Mississippi 39269
Copies of this report can be purchased from:

U.S. Geological Survey

Books and Open-File Reports

Building 810

Federal Center, Box 25425

Denver, Colorado 80225 


\section{CONTENTS}

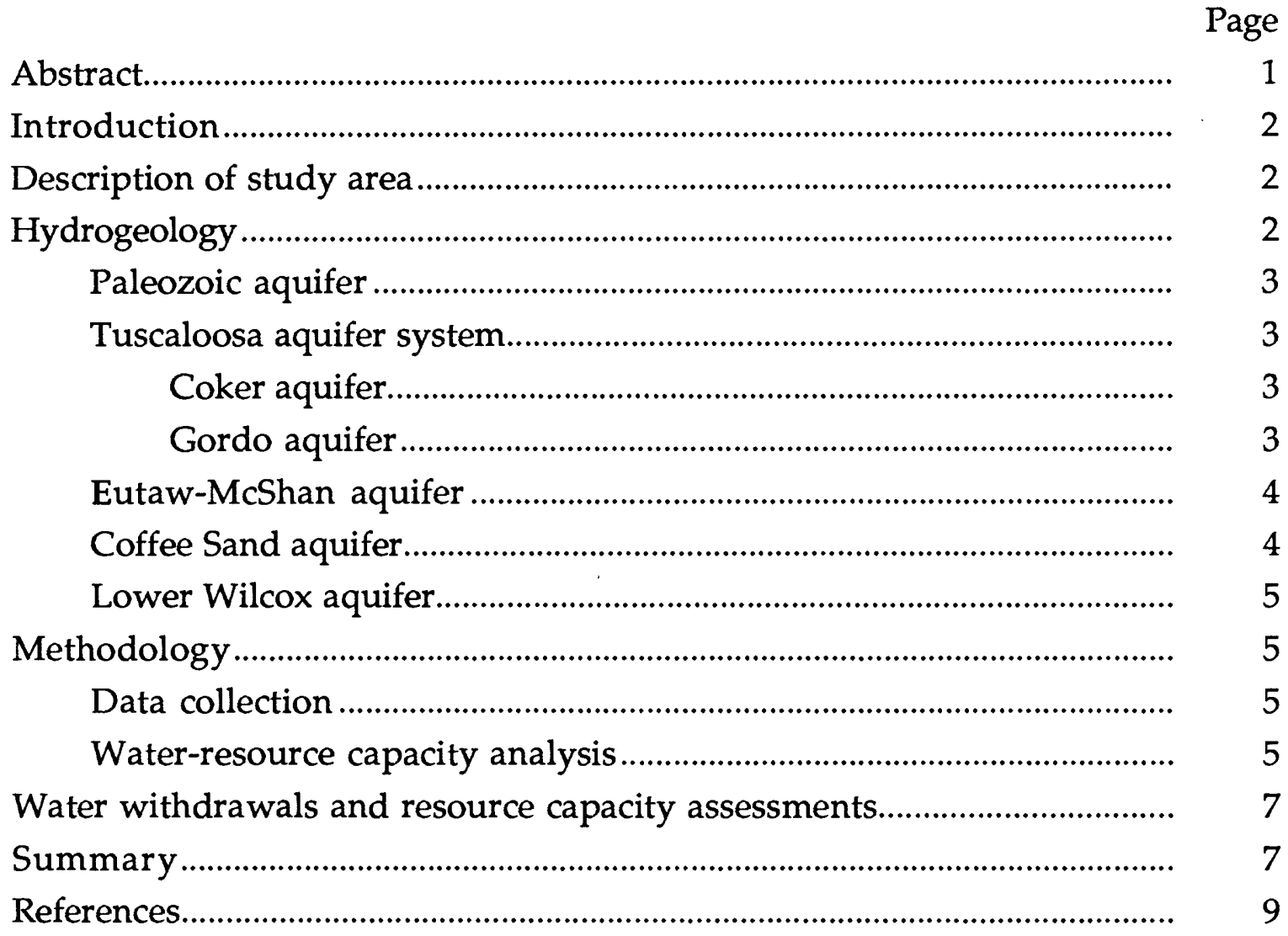




\section{ILLUSTRATIONS}

Page

Figure 1. Map showing location of study area .............................................. 10

2. Map showing major streams in the study area............................. 11

3.- 19. Maps showing location of withdrawals for systems in:

3. Alcorn County, Mississippi .............................................................. 12

4. Chickasaw County, Mississippi........................................................ 13

5. Clay County, Mississippi ................................................................. 14

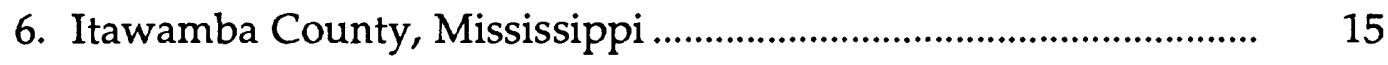

7. Kemper County, Mississippi .......................................................... 16

8. Lauderdale County, Mississippi...................................................... 17

9. Lee County, Mississippi .................................................................. 18

10. Lowndes County, Mississippi......................................................... 19

11. Monroe County, Mississippi …….................................................. 20

12. Noxubee County, Mississippi............................................................ 21

13. Oktibbeha County, Mississippi........................................................ 22

14. Pontotoc County, Mississippi .......................................................... 23

15. Prentiss County, Mississippi.......................................................... 24

16. Tishomingo County, Mississippi .................................................... 25

17. Union County, Mississippi ................................................................ 26

18. Webster County, Mississippi ........................................................... 27

19. Winston County, Mississippi........................................................... 28

\section{TABLES}

Table 1. Geologic units and principal aquifers in the study area............. 29

2. Water withdrawal and risk rating for public supplies, $1985 \ldots \ldots . . \quad 30$

3. Public-supply withdrawal locations................................................ 33

4. Water withdrawals and risk rating for self-supplied

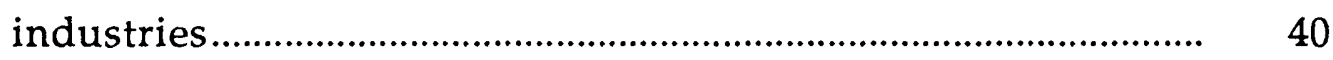

5. Self-supplied industrial withdrawal locations.............................. 41

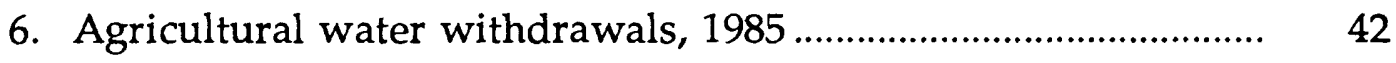

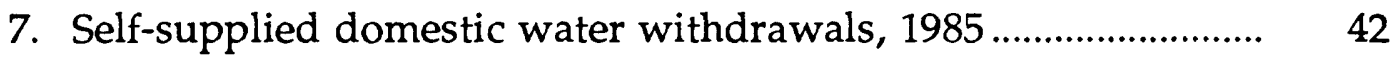




\section{CONVERSION FACTORS}

For readers who prefer to use metric (International System) units, rather than the inch-pound units used in this report, the following conversion factors may be used:

Multiply inch-pound units

foot $(\mathrm{ft})$

square mile $\left(\mathrm{mi}^{2}\right)$

gallon per minute ( $\mathrm{gal} / \mathrm{min}$ )

foot squared per day $\left(\mathrm{ft}^{2} / \mathrm{d}\right)$

million gallons per day (Mgal/d)
By To obtain metric units

0.3048 meter (m)

2.590 square kilometer $\left(\mathrm{km}^{2}\right)$

0.06308 liter per second $(\mathrm{L} / \mathrm{s})$

0.09290 meter squared per day $\left(\mathrm{m}^{2} / \mathrm{d}\right)$

0.04381 cubic meter per second $\left(\mathrm{m}^{3} / \mathrm{s}\right)$ 


\title{
WATER WITHDRAWALS IN THE BLACK WARRIOR-TOMBIGBEE BASIN AND ALCORN COUNTY, MISSISSIPPI, 1985-87
}

\author{
By Nancy L. Barber
}

\begin{abstract}
Public-supply and industrial water withdrawals were inventoried for the Mississippi part of the Black WarriorTombigbee Basin and for Alcorn County, Mississippi. The study area, located in the northeastern part of the State, is largely forested or agricultural land, with some industries near the larger towns. A water-resource capacity analysis was done to determine a risk rating for each inventoried facility, evaluating the likelihood of the facility exceeding the capacity of its current source of water at the existing level of use. Published reports and potentiometric maps were used in this analysis to determine the source capacity and the effects withdrawals have had on each water source.

The public-supply and industrial water withdrawals in the basin are from ground water, with the exception of the city of Columbus. About 97 percent of the total withdrawal of 80 million gallons per day is from ground water. Water-supply systems in three areas were determined to have a high risk of exceeding the water-resource capacity: the Tupelo-Lee County area, the West Point (Clay County) area, and the Starkville (Oktibbeha County) area.
\end{abstract}




\section{INTRODUCTION}

This report and a companion report for Alabama, "Water withdrawals in the Black Warrior-Tombigbee Basin in Alabama, 1985-87" (Mooty, 1990), are the result of a project conducted by the U.S. Geological Survey and funded by the U.S. Army Corps of Engineers. The study area in Mississippi includes all or part of 18 counties within the Black Warrior-Tombigbee Basin, and Alcorn County (fig. 1).

This report presents an inventory of the amount, source, and location of water withdrawals for public-supply and industrial purposes within the study area. Each public-supply and industrial facility is rated as having a "high", "medium", or "low" risk of exceeding the water-resource capacity at the current (1985-87) level of withdrawal. Estimates of other types of water withdrawals such as self-supplied domestic and irrigation also are included.

\section{DESCRIPTION OF STUDY AREA}

The Black Warrior-Tombigbee Basin in Mississippi is located in the northeastern part of the State, and has a drainage area of about 6,175 $\mathrm{mi}^{2}$ (square miles). Approximately 28 percent of the Black Warrior-Tombigbee Basin is in Mississippi. Because of increasing public interest, the study area also includes Alcorn County, which has an area of $409 \mathrm{mi}^{2}$ and is located in the Middle Tennessee-Elk, the Lower Tennessee, and the Lower MississippiHatchie Basins (Seaber and others, 1984).

The larger towns in the study area are Columbus (1984 population 28,658), Tupelo $(25,488)$, Starkville $(16,719)$, Corinth $(12,560)$, West Point $(9,022)$, Amory $(7,340)$, and Aberdeen $(7,159)$ (U.S. Bureau of the Census, 1986). Much of the area is forested or is used for agriculture, although some small industries are located near these larger towns.
The study area encompasses parts of five physiographic provinces: the Fall Line Hills, the Black Belt, Pontotoc Ridge, the Flatwoods, and the North-Central Plateau (Thornbury, 1965, p. 53-55). The upper reaches of the Tombigbee River flow through the Fall Line Hills, an area of generally poor soils with local relief as much as $300 \mathrm{ft}$ (feet). In Monroe County and areas farther south, the river closely follows the boundary between the Fall Line Hills province and the Black Belt, an area of gently rolling topography and very rich soils. Farther west, the Black WarriorTombigbee basin includes part of Pontotoc Ridge, an escarpment which stands up to $200 \mathrm{ft}$ higher in elevation than the Black Belt, and the Flatwoods province, an area of low to moderate relief and clayey soils. The southern part of the basin is in the North-Central Plateau, also an area of low relief.

\section{HYDROGEOLOGY}

Major streams in the study area are the Tombigbee River and its tributaries, Mackeys Creek, Bull Mountain Creek, Buttahatchee River, Luxapallila Creek, and the Noxubee River (fig. 2). The Tennessee-Tombigbee Waterway, completed in 1984, provides a more direct route for barge traffic from the Tennessee River in Tishomingo County to the Gulf of Mexico by way of the Tombigbee River. Because of the ready availability of ground water in much of the basin, the only entity in the study area obtaining part of its water supply from surface-water sources is the City of Columbus water system.

Ground water is available in all parts of the basin. The underlying sedimentary rocks contain a number of aquifers that are used for water supply. The rocks generally dip to the west and southwest in this area. Outcrop areas of the water-bearing formations are recharge zones, and the freshest water occurs in or near the outcrop area in all of the aquifers. 


\section{Paleozoic Aquifer}

The Paleozoic aquifer, which occurs primarily in the upper, weathered zone in rocks of Paleozoic age (Darden, 1984b), is present in the extreme northeastern part of the study area. The Paleozoic rocks outcrop in Tishomingo County. In most of the study area, the Paleozoic rocks are overlain by the Gordo Formation (table 1). In Alcorn and Tippah Counties, where the Gordo is not present, the Paleozoic rocks are directly overlain by the McShan Formation or the Eutaw Formation where the McShan is not present (Boswell, 1977). The overlying units are in good hydraulic contact with the Paleozoic rocks in places (Wasson, 1986, $p$. 102). The Paleozoic aquifer is composed of weathered limestone, chert, and sandstone, and averages about $100 \mathrm{ft}$ in thickness. Productivity of the aquifer varies, but can be high lyield of $1,000 \mathrm{gal} / \mathrm{min}$ (gallons per minute)]. Average transmissivity is about $4,000 \mathrm{ft}^{2} / \mathrm{d}$ (feet squared per day)].

Large withdrawals from the Paleozoic aquifer are occurring at Corinth, in Alcorn County, where the aquifer is confined. Water-level declines of as much as $15 \mathrm{ft} / \mathrm{yr}$ (feet per year) were observed in the 1970's, indicating that withdrawals were exceeding the rate of recharge (Wasson and Tharpe, 1975). Since that time, the pumpage has been distributed over a wider area around Corinth, and the cone of depression has become shallower but more extensive areally. The lowest water-levels at Corinth were measured during 1974 (Darden, 1984b).

\section{Tuscaloosa Aquifer System}

The Tuscaloosa aquifer system, in rocks of the Tuscaloosa Group of Late Cretaceous age, is composed of the combined Coker and Gordo aquifers (Boswell, 1963). Wells are designated as being completed in the Tuscaloosa aquifer system when an exact formational designation is not known.

\section{Coker Aquifer}

The Coker aquifer is composed of the massive basal sand of the Coker Formation of Late Cretaceous age (Boswell, 1978) which is present in the subsurface of the southern two-thirds of the study area and outcrops in western Alabama. The Coker Formation is underlain by rocks of Paleozoic age in northern Mississippi and by Lower Cretaceous rocks in the southern part of the study area, and is overlain by the Gordo Formation (table 1). Both underlying and overlying units are hydraulically connected to the Coker Formation to some degree. Upper units of the underlying Lower Cretaceous rocks may be included in the Coker aquifer where they contain freshwater. The Coker aquifer generally is 400 to $600 \mathrm{ft}$ thick in the areas where it is used, although in Monroe County it is thinner and the effects of pumpage are more pronounced. The aquifer is very productive, with yields of 1,500 to $1,800 \mathrm{gal} / \mathrm{min}$ from large wells (Boswell, 1978).

The Coker aquifer was not developed in the study area until recently, because the overlying Gordo aquifer provided a shallower source of water. Declining water levels in the Gordo are leading to increased development of the Coker.

\section{Gordo Aquifer}

The Gordo aquifer is composed of sand and gravel in the lower part of the Gordo Formation (table 1). The Gordo Formation is of Late Cretaceous age and is present in much of the study area (Boswell, 1963). The aquifer is underlain by rocks of Paleozoic age in the northern part of the study area, and elsewhere by the Coker Formation. A thick clay bed in the upper part of the Coker Formation serves as a confining unit (Wasson, 1986). The Gordo aquifer is overlain and partially confined by an upper clay unit in the Gordo Formation. Yields from large wells in the Gordo aquifer range from 500 to 1,000 $\mathrm{gal} / \mathrm{min}$, and the transmissivity of the aquifer ranges from 500 to $21,000 \mathrm{ft}^{2} / \mathrm{d}$ (Boswell, 1963). 
The Gordo aquifer is pumped heavily in the study area. Three cones of depression in the potentiometric surface are centered around pumping in the Tupelo area in Lee County, Lowndes County, and the Starkville-West Point-Aberdeen area. Water levels in an observation well in the Tupelo area declined at a rate of about 5 ft/yr during the period 1966 to 1978 (Wasson, 1980a). Between 1978 and 1988, the cone of depression did not deepen, but expanded areally (Goldsmith, 1988). The cone of depression in Lowndes County became shallower between 1978 and 1988 because of decreased pumping in the area. Water levels in areas near Starkville and West Point declined more than $3 \mathrm{ft} / \mathrm{yr}$ between 1978 and 1988.

\section{Eutaw-McShan Aquifer}

The Eutaw-McShan aquifer is composed of the permeable parts of the Eutaw Formation and the underlying McShan Formation, both of which are Late Cretaceous in age. The Gordo Formation underlies the McShan Formation (table 1), and the Eutaw Formation is overlain by the Coffee Sand in the northern part of the study area and by the Mooreville Chalk in the southern part. Clays in the upper Gordo Formation separate the Gordo aquifer from the Eutaw-McShan aquifer in the southern part of the study area. In the northern part of the study area, some hydraulic connection exists between the EutawMcShan aquifer and the underlying Gordo aquifer where present, or between the Eutaw-McShan and the Paleozoic aquifer. The Eutaw-McShan aquifer is in some hydraulic connection to the overlying Coffee Sand aquifer. Where the Mooreville Chalk is present, it acts as an overlying confining unit (Boswell, 1977). The Eutaw-McShan is composed of thin beds of fine- to medium-grained sand, and clay. Irregular lenses of sand are more extensive in the Eutaw Formation. The Tombigbee Sand Member of the Eutaw Formation is a massive, fine-grained sand (Boswell, 1977). The Eutaw-McShan aquifer ranges in thickness from $100 \mathrm{ft}$ in the northern part of the basin, to about $420 \mathrm{ft}$ in the southern part. The aquifer is the least productive of the major aquifers in Mississippi, with well yields ranging from 100 to $770 \mathrm{gal} / \mathrm{min}$, and transmissivity values between 200 and 4,900 ft $/ \mathrm{d}$ (Gandl, 1982, p. 3).

The Eutaw-McShan aquifer is widely used because it is the shallowest source of ground water in many parts of the study area. During 1988, cones of depression in the potentiometric surface were present in Lee County (the Tupelo area) and in Clay County (West Point). The water levels near Tupelo declined more than $4 \mathrm{ft} / \mathrm{yr}$ between 1982 and 1988. The cone of depression near West Point did not deepen, but spread areally into Lowndes County during the same period (Goldsmith, 1988).

\section{Coffee Sand Aquifer}

The Coffee Sand aquifer, in rocks of the Coffee Sand, is part of the Selma Group of Late Cretaceous age (table 1). The aquifer is present in the northern part of the study area, but in Lee County the unit grades into the Mooreville Chalk (Boswell, 1979). The Coffee Sand crops out in eastern Alcorn, Prentiss, and northern Lee Counties. The aquifer is overlain and confined by the Demopolis Chalk of Late Cretaceous age, and is underlain by the Eutaw Formation and rocks of Paleozoic age. Some hydraulic connection exists between the Coffee Sand and the Eutaw-McShan aquifer. The Coffee Sand aquifer is composed of thin beds of fine- to medium-grained sand and clay, and is about $200 \mathrm{ft}$ thick (Boswell, 1963). Wells in the Coffee Sand yield from 50 to 600 $\mathrm{gal} / \mathrm{min}$; transmissivity values range from 930 to $1,200 \mathrm{ft}^{2} / \mathrm{d}$ (Gandl, 1982, p. 3).

The Coffee Sand is not widely used in the study area, because much of the Black Warrior-Tombigbee Basin is in the outcrop area. In the confined zones, the aquifer is used by small public-supply systems as a source of water. 


\section{Lower Wilcox Aquifer}

The lower Wilcox aquifer occurs in the extreme southern part of the study area in Kemper, Lauderdale, and Clarke Counties. It consists of the lower sand beds of the Wilcox Group, of Tertiary (Paleocene and Eocene) age and, in places, sand beds in the upper part of the underlying Midway Group of Paleocene age (Boswell, 1975). The lower Wilcox aquifer is underlain and confined by thick clays in the Midway Group, and is overlain and confined by clays in the middle part of the Wilcox Group (Wasson, 1966 , p. 66). The majority of the lower Wilcox aquifer occurrence in the study area consists of the aquifer outcrop area. In the outcrop area, the aquifer may be as much as $1,200 \mathrm{ft}$ thick, but in the confined zone the lower Wilcox aquifer averages about $200 \mathrm{ft}$ in thickness. The aquifer is very productive in the study area (Wasson, 1980), with some wells yielding more than $2,000 \mathrm{gal} / \mathrm{min}$.

Water-level measurements made in the lower Wilcox aquifer during 1979 and 1982 have shown little or no change in water levels in and near the outcrop area. The highest water levels are in the aquifer outcrop area in Winston County (Darden, 1986).

\section{METHODOLOGY}

\section{Data Collection}

Water-use information was collected from several sources. When available, information on public-supply system withdrawals was assembled from pumpage records supplied by the system operator. Billing records were used when pumpage data were not available. When neither of these records was available, water withdrawal rates were estimated using information about the capacity of the system and the number of customers served. The number of service connections was supplied by the system operator and the population served was estimated by assuming that each household (customer) consisted of 3.2 persons, the 1970 average for the State (U.S.
Bureau of the Census, 1981). Some population-served values were supplied by the system operators.

Industrial withdrawals were compiled from information supplied by the industries. Industries generally were contacted by phone, and detailed withdrawal records were obtained when available. If the industrial facility's withdrawals were not metered, the withdrawal rate was estimated using information on the well capacity and hours of operation. The number of employees was obtained from the industry; the Standard Industrial Classification (SIC) Codes were obtained from the 1986 Mississippi Manufacturer's Directory (Vallados, 1986).

Aquifer and location information for both public-supply and industrial wells was obtained from the U.S. Geological Survey's Ground-Water Site Inventory data base, and was verified by plotting the reported locations using a geographic information system.

Aggregated data, such as livestock, irrigation, and self-supplied domestic water use, were estimated for 1985 as part of the National Water Use Information Program of the U.S. Geological Survey. These data were retrieved from the Mississippi Aggregated Water Use Data System for the counties in the study area.

\section{Water-Resource Capacity Analysis}

Water-supply problems may arise because of the hydraulic characteristics of the water source, or as the result of human activities. Aquifer characteristics, such as low transmissivity, may limit the amount of water that can be obtained from wells without causing excessive drawdowns.

Most of the identified problem areas in Mississippi result from human activities. When pumping begins in an area, the water levels near the well or well field will decline. If there is a sufficient supply of water in the aquifer, and the aquifer is able 
to transmit that water readily, the water level will stabilize until the pumping rate changes or the supply of water in the aquifer changes (such as a reduction in recharge during a drought). Conversely, if the supply of water in the aquifer is not adequate or if the aquifer is not able to readily transmit the water as quickly as it is being withdrawn, the water levels will continue to decline. Although the rates of groundwater withdrawals may exceed the recharge rate for many years, dewatering of the aquifer will occur eventually. Long-term water-level trends give an indication as to whether the aquifer is being pumped at a rate greater than the recharge rate.

Each public-supply and industrial water source was evaluated as to the risk of its capacity being exceeded if the 1985-87 level of usage were maintained. The risk rating for each ground-water user was based on aquifer characteristics, water quality, and the trend in water levels near the withdrawal point. The rate of water withdrawal also was considered, because lower pumping rates can be sustained longer than higher ones under the same conditions. Most of the identified high- and moderaterisk areas in Mississippi result from waterquantity problems, as indicated by longterm water-level declines. The risk assessments were made based on published reports and on available potentiometric maps. No new geologic or hydrologic data were collected for these analyses. The ratings for entities using ground water are subjective and were determined from generalized information about the aquifers. Detailed analysis of a specific well or well field might result in a different risk rating.

Ground-water users with a "low" risk of water-supply problems generally are in areas where available evidence indicates little or no long-term decline in water levels in the aquifer being used and the user has a low or moderate water demand.
Water users with a "moderate" risk of water-supply problems may:

- have a large withdrawal rate with little or no evidence of water-level declines (less than $1 \mathrm{ft} / \mathrm{yr}$ ),

- be located in an area of general waterlevel declines but have a smaller withdrawal than other users in that area,

- be withdrawing water from an aquifer in or near the outcrop area (more susceptible to drought),

- be withdrawing water from an aquifer with lower transmissivity, or

- be withdrawing water from an area where water with objectionable water-quality characteristics (such as high concentrations of dissolved solids) is close to the withdrawal point, and the supply is therefore more susceptible to water-quality problems.

Water users with a "high" risk of water supply problems are those in an area where water levels are declining more than $2 \mathrm{ft} / \mathrm{yr}$, or in an area where the declines are less than $2 \mathrm{ft} / \mathrm{yr}$ but the user withdraws more water than other users in the area.

Because of differences in geologic setting and data availability, the risk analysis for ground-water users in the companion report for Alabama was based more on water quality and aquifer characteristics.

The analysis of the risk of water-supply problems for the system using surface water, the City of Columbus, was made by comparing the 1985 rate of withdrawal with the 7-day, 10-year low flow for Luxapallila Creek at the withdrawal point. The risk analysis for systems using 
surface water described in the companion report for Alabama also compared the current (1985-87) withdrawal rate to the 7-day, 10-year low flow for each site.

\section{WATER WITHDRAWALS AND}

\section{RESOURCE CAPACITY ASSESSMENTS}

Water withdrawals for public suppliers and industries are shown in tables 2 and 4 . All information for public suppliers is for 1985; information for industrial facilities is for 1985,1986 , or 1987. Industrial facilities are listed in table 4 by Standard Industrial Classification category. The withdrawal locations in each county are shown in figures 3-19. Locations are plotted on a map of the county where the water system or facility is located. Some points are shown outside the county boundary because some water systems own wells in adjacent counties. Withdrawal locations are numbered sequentially on each map. These numbers refer to tables 3 and 5 .

About 97 percent of the 80 million gallons per day (Mgal/d) of water withdrawn by public suppliers and industries was from ground-water sources. The Gordo aquifer supplied about one-half of this water. The City of Columbus is the only entity that uses surface water.

The largest withdrawals for public supply in the study area during 1985 were for: the city of Tupelo in Lee County (6.274 $\mathrm{Mgal} / \mathrm{d}$ from the Gordo and Eutaw-McShan aquifers), the city of Columbus in Lowndes County (5.518 Mgal/d from the Coker aquifer and Luxapallila Creek), and the city of Corinth in Alcorn County $(3.617 \mathrm{Mgal} / \mathrm{d}$ from the Paleozoic aquifer). About 95 percent of the $43.84 \mathrm{Mgal} / \mathrm{d}$ withdrawn for public supply was from ground water.

Few industries in the study area supply their own water; most purchase water from a public-supply system. However, the industries which require the largest volumes of water generally are the ones that are selfsupplied. The largest withdrawals for industrial use are in Monroe County (from the Gordo aquifer), and in Lowndes County (from the Coker and Gordo aquifers). All of the $35.74 \mathrm{Mgal} / \mathrm{d}$ of self-supplied industrial water was from ground water.

Agricultural water withdrawals for irrigation and livestock watering are small (table 6). Irrigation withdrawals for the 19 counties which are wholly or partially in the study area were $1.12 \mathrm{Mgal} / \mathrm{d}$ during 1985 , 41 percent from ground water. Livestock withdrawals were estimated to be 7.85 $\mathrm{Mgal} / \mathrm{d}$ during 1985, about 68 percent from ground water.

Self-supplied domestic water use in the study area is relatively small because the percentage of the population in the study area that supplies their own water is small (table 7). In 10 of the 19 counties in the study area, less than 5 percent of the population supplies its own water. Many of the public supply systems are rural water associations that serve customers who formerly used private wells. Noxubee County has the largest percentage of people who supply their own water (39 percent).

Three areas where water withdrawers may have a high risk of water-supply problems were identified: the Tupelo area, including most of Lee County; the West Point area in Clay County; and the Starkville area in Oktibbeha County. Major waterlevel declines have occurred in both the Gordo and the Eutaw-McShan aquifers in Lee County. These aquifers also are experiencing water-level declines near West Point, as is the Gordo aquifer in the Starkville area. Facilities which withdraw moderate-to-large volumes of water in these areas have a high risk of experiencing water-supply problems.

\section{SUMMARY}

The amount, source, and location of water withdrawals for public-supply and industrial purposes during the period 1985-87 were inventoried for the Black Warrior-Tombigbee Basin and Alcorn 
County in northeastern Mississippi. A water-resource capacity analysis was done to determine a risk rating for each inventoried facility, evaluating the likelihood of the facility exceeding the capacity of its current source of water at the existing level of use.

The public-supply and industrial water withdrawals in the basin are from ground water, with the exception of the City of Columbus. About 97 percent of the total withdrawal of $80 \mathrm{Mgal} / \mathrm{d}$ is from ground water. Three areas were found to have a relatively high risk of exceeding the water-resource capacity: the Tupelo-Lee County area, the West Point (Clay County) area, and the Starkville (Oktibbeha County) area. 


\section{REFERENCES}

Boswell, E. H., 1963, Cretaceous aquifers of northeastern Mississippi: Mississippi Board of Water Commissioners Bulletin 63-10, $202 \mathrm{p}$.

--.- 1975, The lower Wilcox aquifer in Mississippi: U.S. Geological Survey Water-Resources Investigations 60-75, 3 sheets.

---- 1977, The Eutaw-McShan aquifer in Mississippi: U.S. Geological Survey Water-Resources Investigations 76-134, 2 sheets.

--- 1978, The Tuscaloosa aquifer system in Mississippi: U.S. Geological Survey Water-Resources Investigations 78-98, 3 sheets.

---- 1979, The Coffee Sand and Ripley aquifers in Mississippi: U.S. Geological Survey Water-Resources Investigations 78-114, 1 sheet.

Darden, Daphne, 1984a, Potentiometric map of the Gordo aquifer in northeastern Mississippi, November and December 1982: U.S. Geological Survey WaterResources Investigations Report 83-4254, 1 sheet.

---- 1984b, Potentiometric map of the Paleozoic aquifer in northeastern Mississippi, November and December 1982: U.S. Geological Survey WaterResources Investigations Report 83-4243, 1 sheet.

----- 1986, Potentiometric map of the lower Wilcox aquifer in Mississippi, fall 1982: U.S. Geological Survey Water-Resources Investigations Report 85-4059, 1 sheet.

Gandl, L.A., 1982, Characterization of aquifers designated as potential drinking water sources in Mississippi: U.S. Geological Survey Open-File Report 81-550, 90 p.

Goldsmith, G.D.S., 1988, Declining water levels in the Gordo and Eutaw-McShan aquifers in Mississippi Water Resources Conference, Eighteenth, Jackson, Mississippi, 1988, Proceedings: Mississippi State, Mississippi, Water Resources Research Institute, p. 34-37.

Mooty, W.S., 1990, Water withdrawals in the Black Warrior-Tombigbee basin in
Alabama, 1985-87: U.S. Geological

Survey Water-Resources Investigations Report 90-4112, 46 p.

Seaber, P.R., Kapinos, F.P., and Knapp, G.L.,1984, State hydrologic unit maps: U.S. Geological Survey Open-File Report 84-708.

Slack, L.J., and Darden, Daphne, 1991, Summary of aquifer tests in Mississippi, June 1942 through May 1988: U.S. Geological Survey Water-Resources Investigations Report 90-4155, 40 p.

Thornbury, W.D., 1965, Regional geomorphology of the United States: New York, John Wiley and Sons, Inc., p. 53-56.

U.S. Bureau of the Census, 1981, 1980 Census of population and housing--Mississippi-Final population and housing unit counts: U.S. Census Bureau Publication Number PHC80-V-26, 20 p.

U.S. Bureau of the Census, 1986, Current population reports--Local population estimates--South 1984 population and 1983 per capita income, estimates for counties and incorporated places: U.S. Census Bureau ser. P-26, no. 84-S-SC, $117 \mathrm{p}$.

Vallados, Lorraine, compiler, 1986, 1986 Mississippi manufacturers directory: Jackson, Mississippi Research and Development Center, 308 p.

Wasson, B.E., 1980a, Potentiometric map of the Gordo aquifer in northeastern Mississippi, November and December 1978: U.S. Geological Survey Open-File Report 79-1586, 1 sheet.

---- 1980b, Potentiometric map of the Sparta aquifer system in Mississippi, fall 1980: U.S. Geological Survey OpenFile Report 81-1051, 1 sheet.

---- 1986, Sources for water supplies in Mississippi: Mississippi Research and Development Center Bulletin, $113 \mathrm{p}$.

Wasson, B.E., and Tharpe, E.J., 1975, Water for industrial development in Alcorn, Itawamba, Prentiss, and Tishomingo Counties, Mississippi: Mississippi Research and Development Center Bulletin, $60 \mathrm{p}$. 


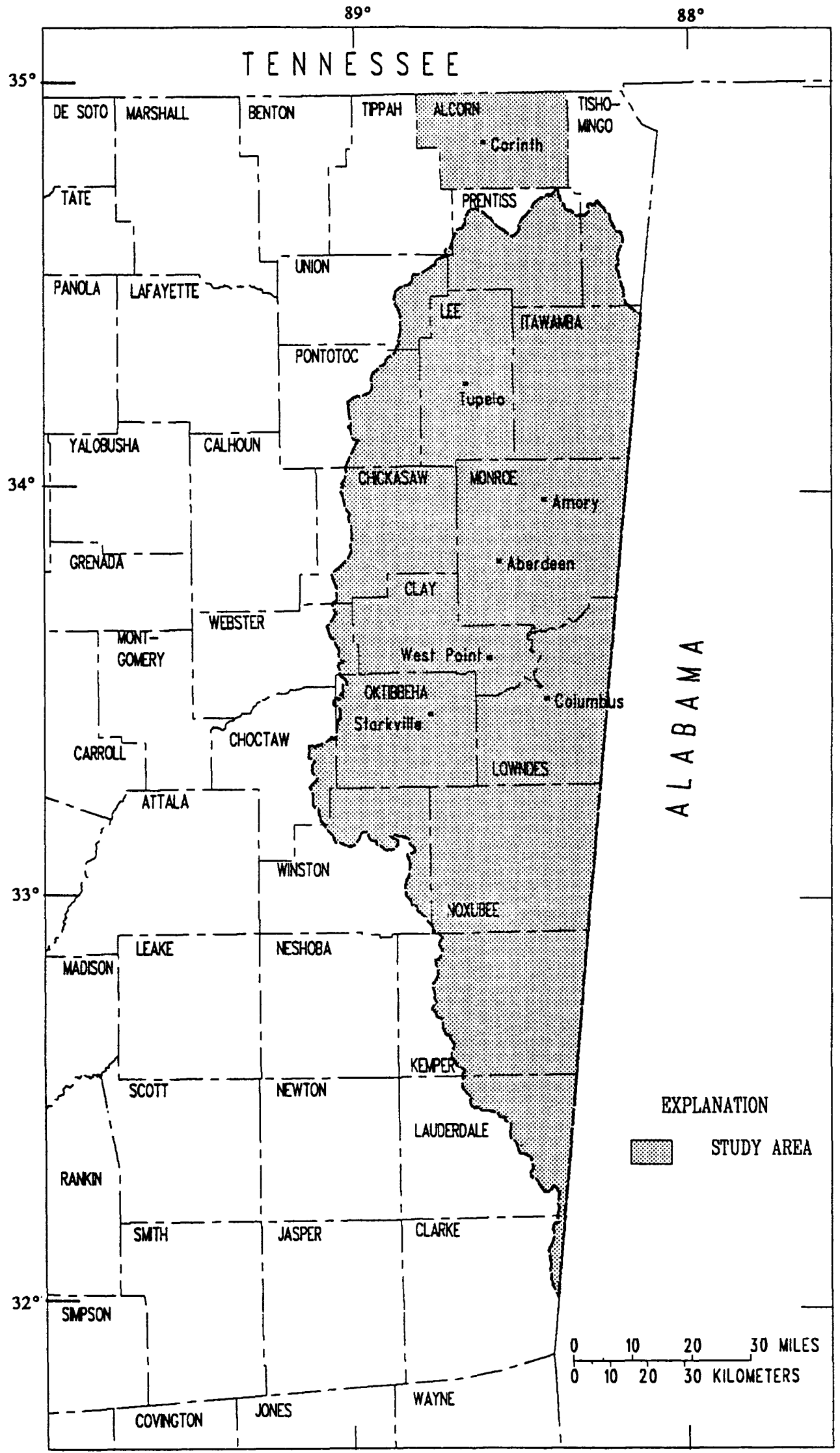

Figure 1.--Location of study area in Mississippi. 


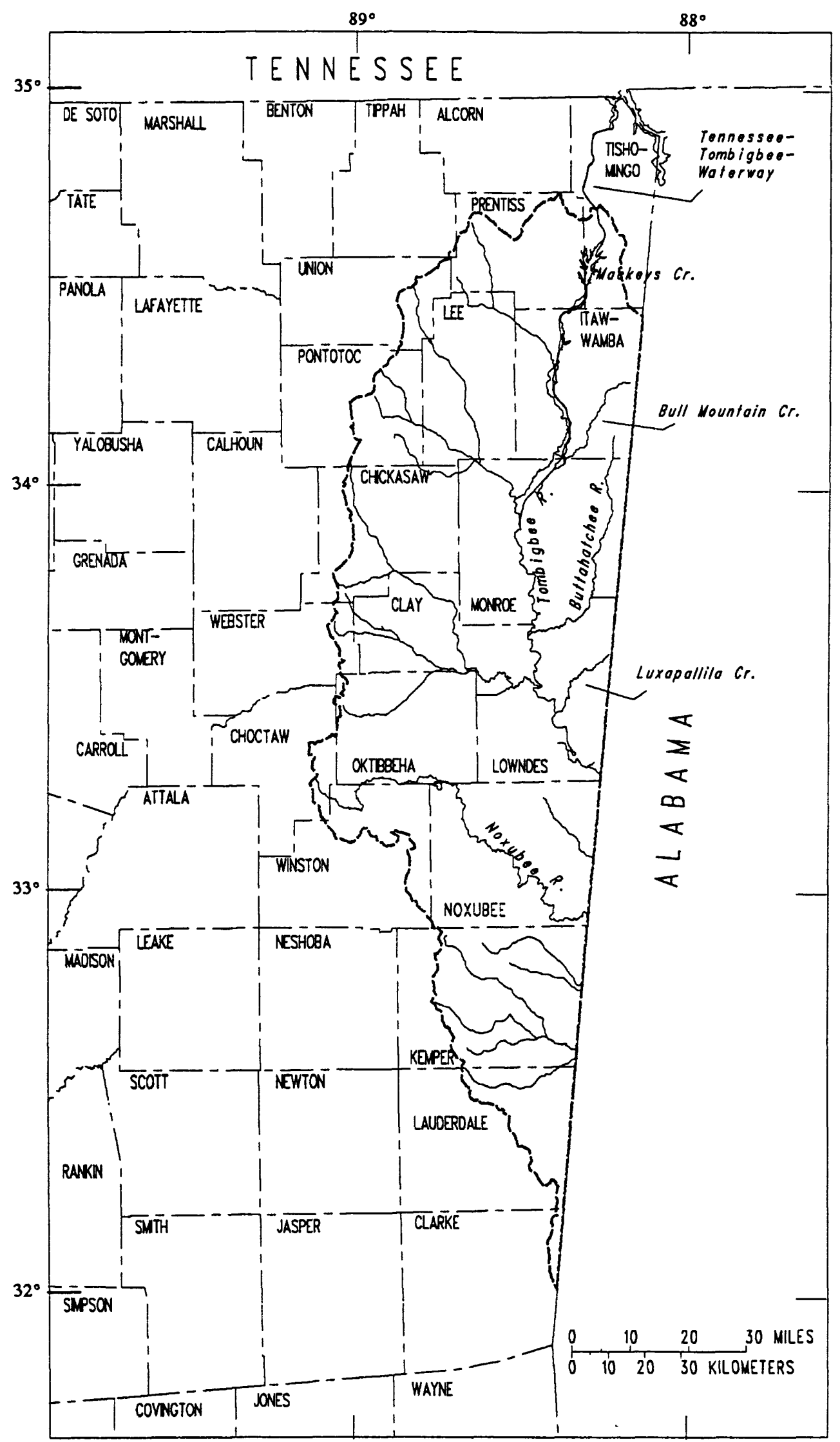

Figure 2.--Major streams in the study area. 


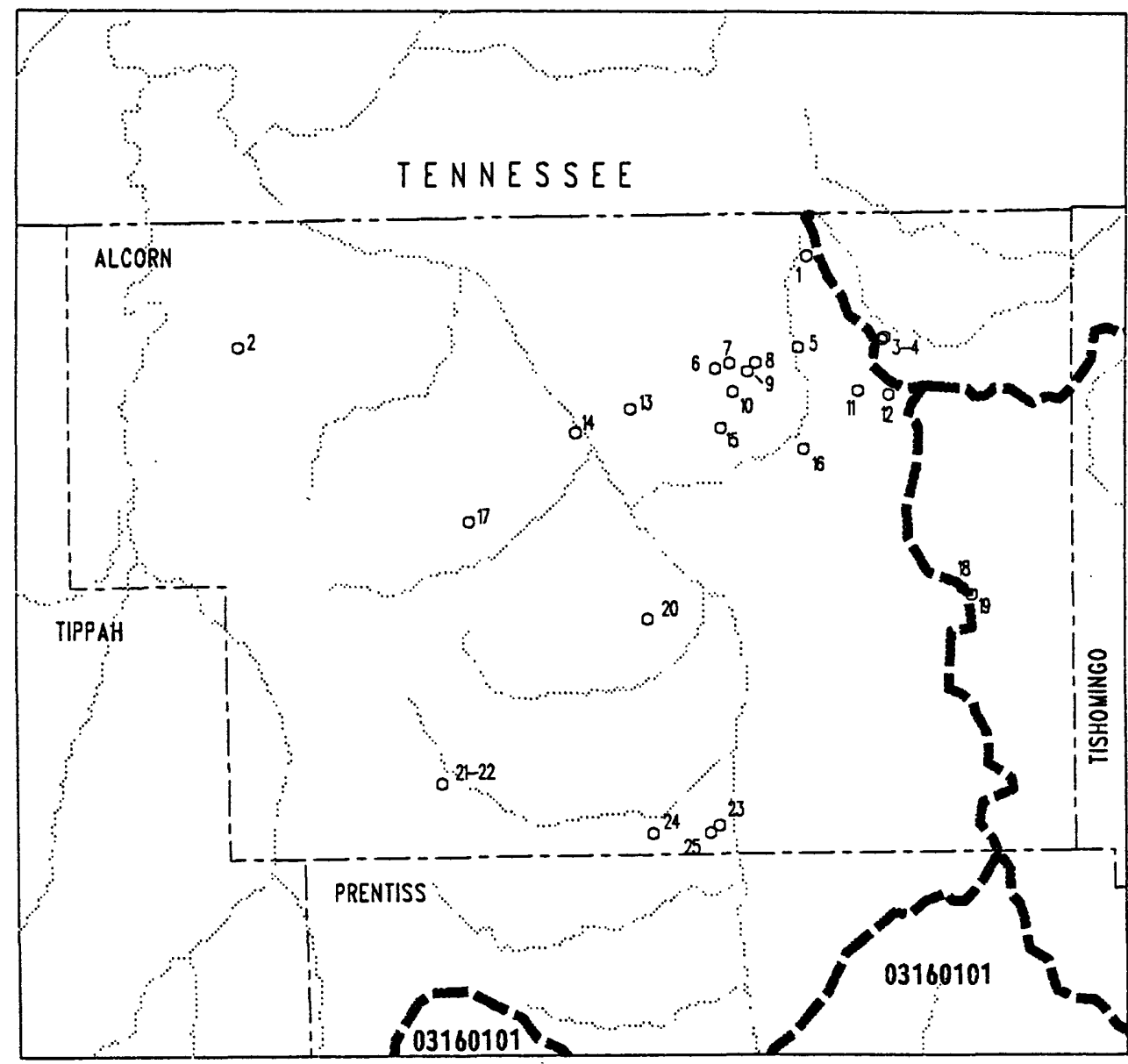

EXPLANATION

O 1 LOCATION OF PUBLLC-SUPPLY MITHDRATAL (NUMBERS REFER TO TABLE 3)

HYDROLOCIC UNIT

BOUNDARY AND CODE

(CODES SHOTN FOR

BLACK WARRIOR-TOMBIGBEE

BASIN ONLY)
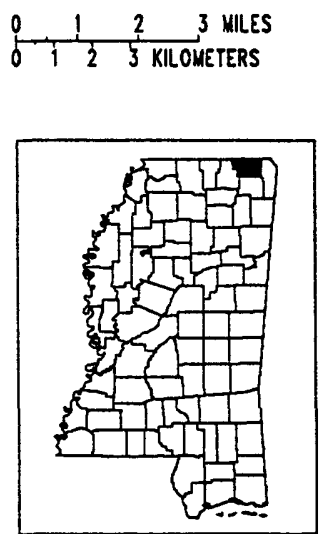

Figure 3.-Location of withdrawals for systems in Alcorn County, Mississippi. 


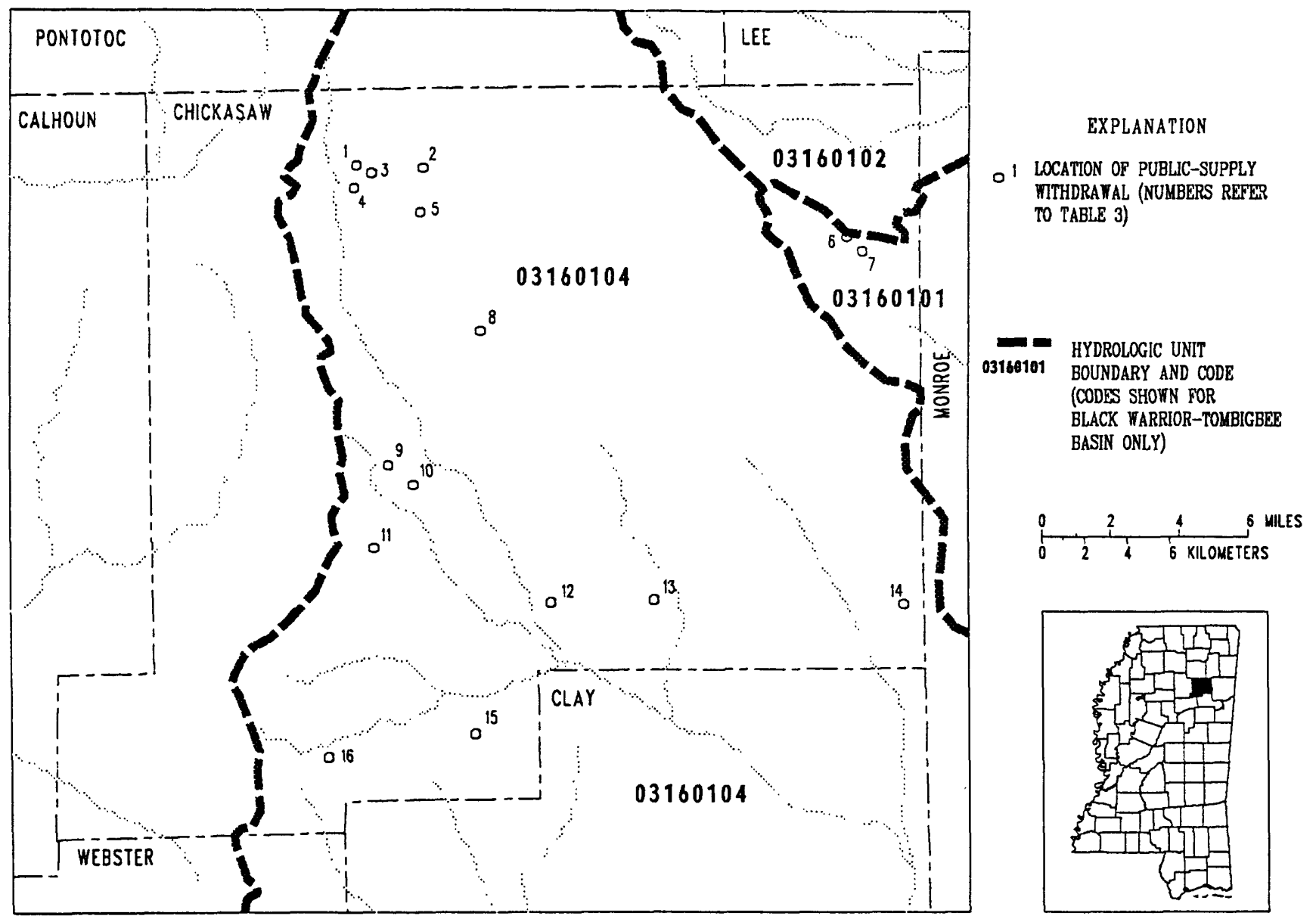

Figure 4.--Location of withdrawals for systems in Chickasaw County, Mississippi. 


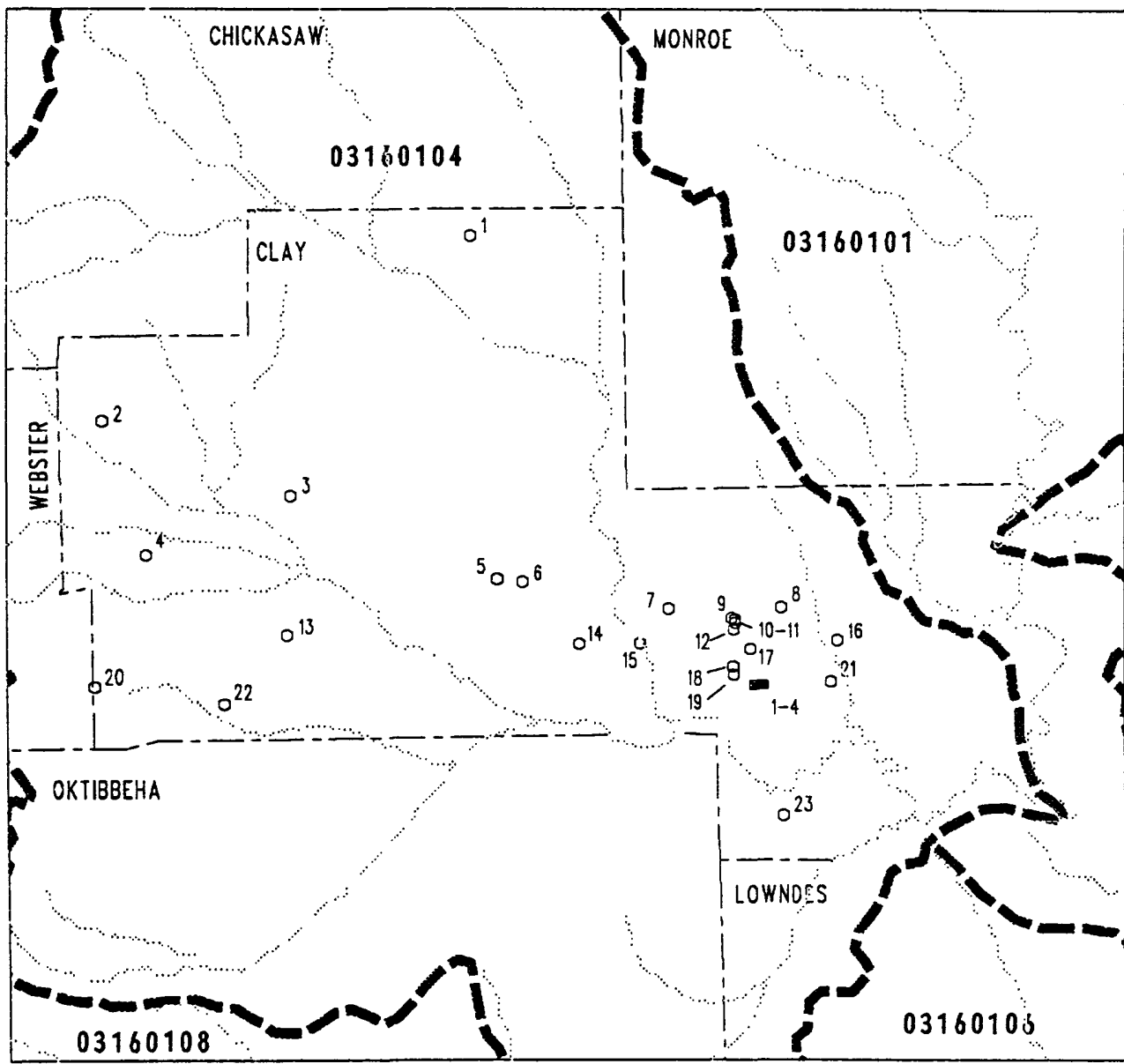

EXPLANATION

- 1 LOCATION OF PUBLIC-SUPPLY MITHDRAWAL (NUMBERS REFER TO TABLE 3)

1 LOCATTON OF INDUSTRIAL

MITHDRA INAL (NUMBERS REFER TO TABLE 5)

HYDROLOGIC UNIT

03160101 BOUNDARY AND CODE

(CODES SHOWN FOR

BLACK YARRIOR-TOMBICBEE BASIN ONLY)
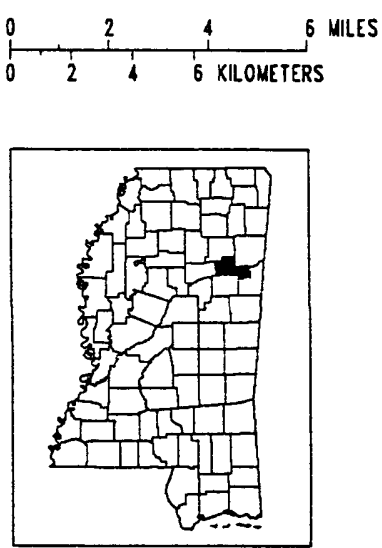

Figure 5.-Location of withdrawals for systems in Clay County, Mississippi. 


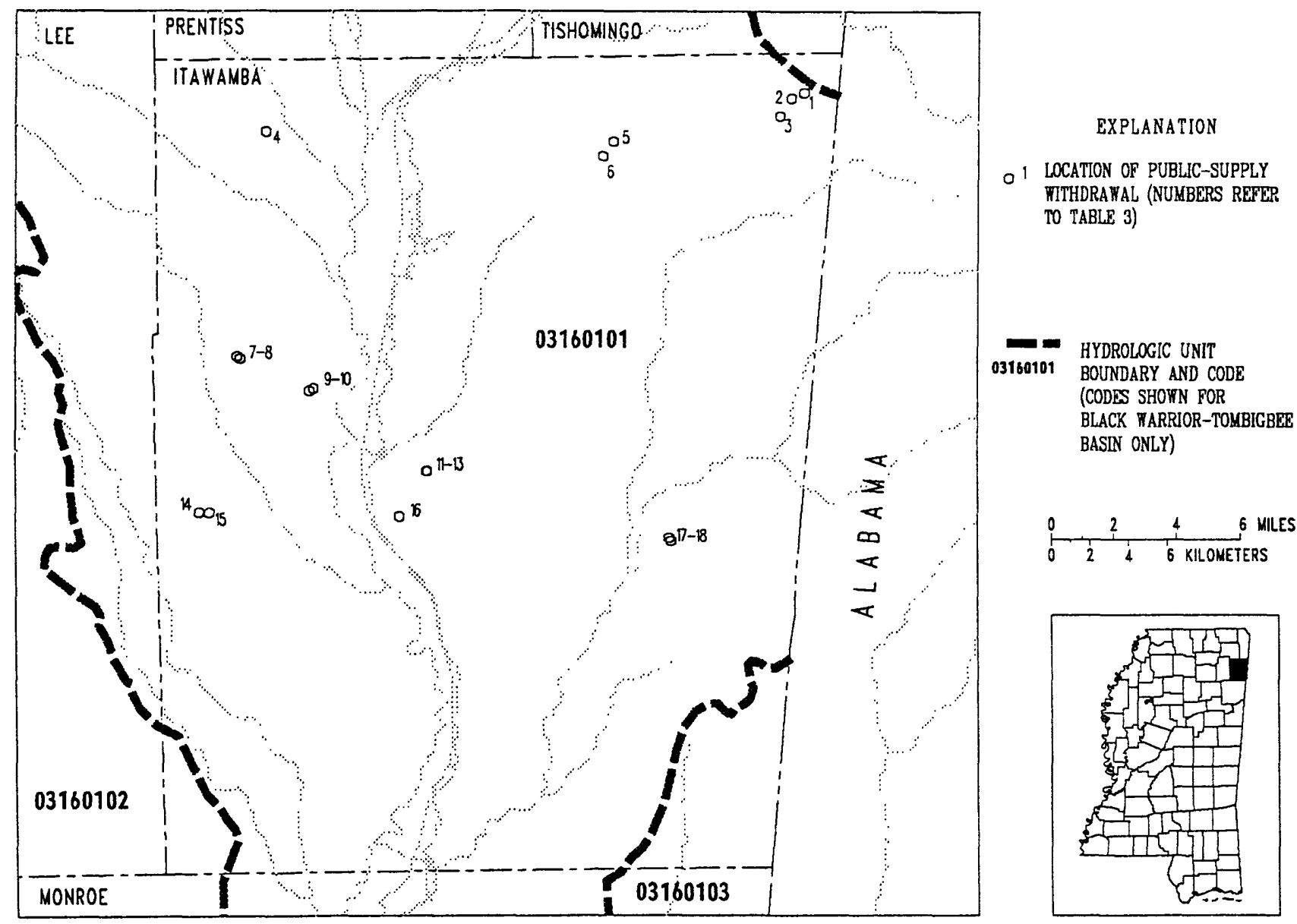

Figure 6.--Location of withdrawals for systems in Itawamba County, Mississippi. 


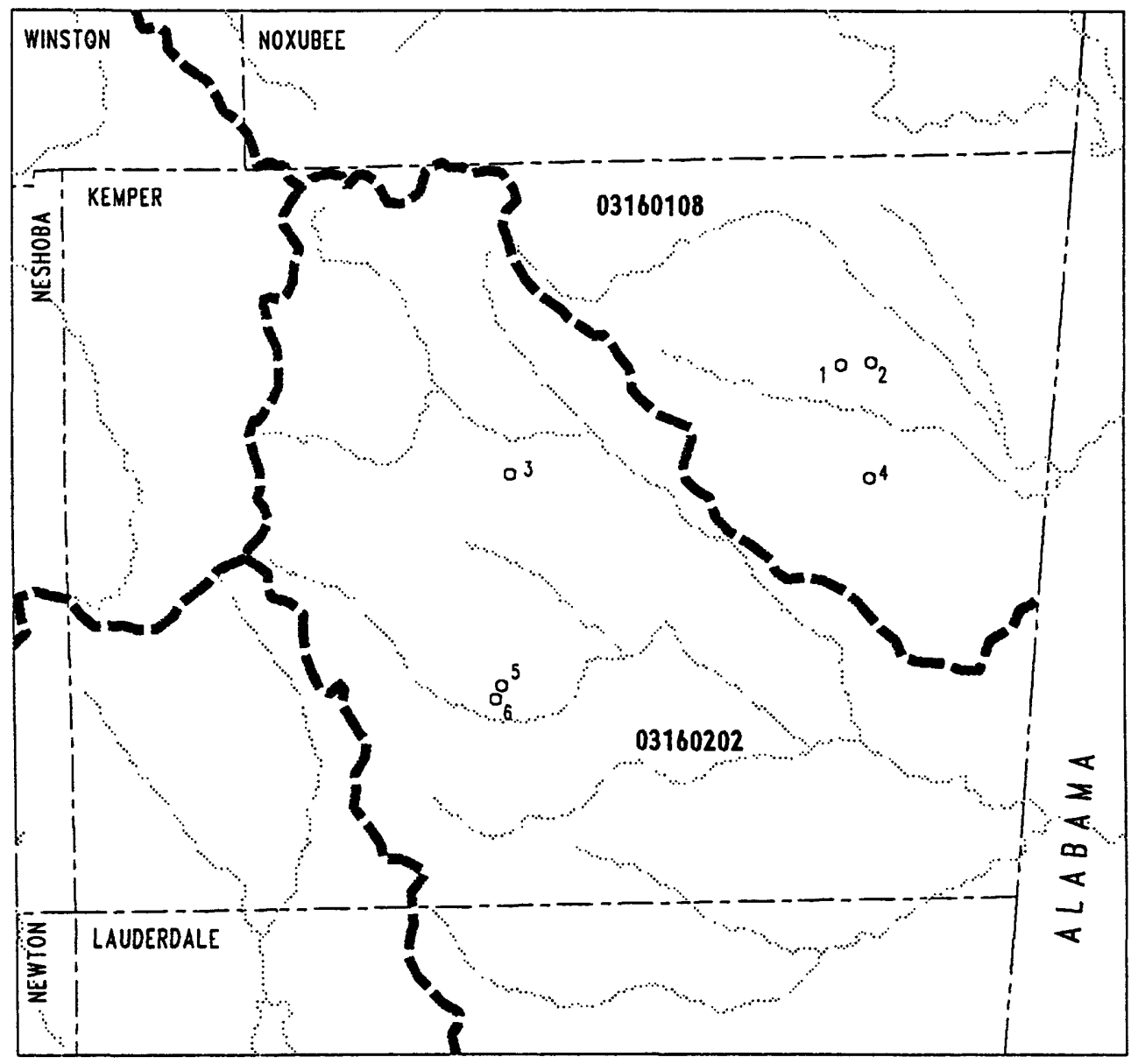

\section{EXPLANATION}

- 1 LOCATTON OF PUBLIC-SUPPLY MTHDRATAL (NUMBERS REPIR TO TABLE 3)

HYDROLOCIC UNIT

03160101 BOUNDARY AND CODE (CODBS SHOWN FOR BLACK TARRIOR-TOYBIGBRE BASIN ONLY)
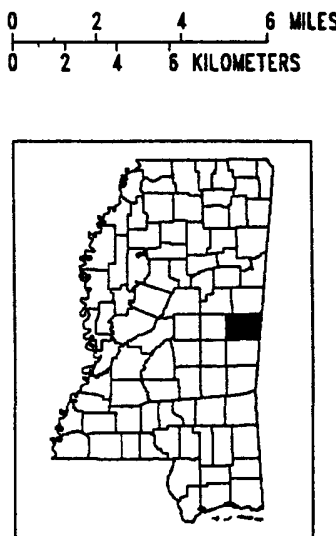

Figure 7.--Location of withdrawals for systems in Kemper County, Mississippi. 


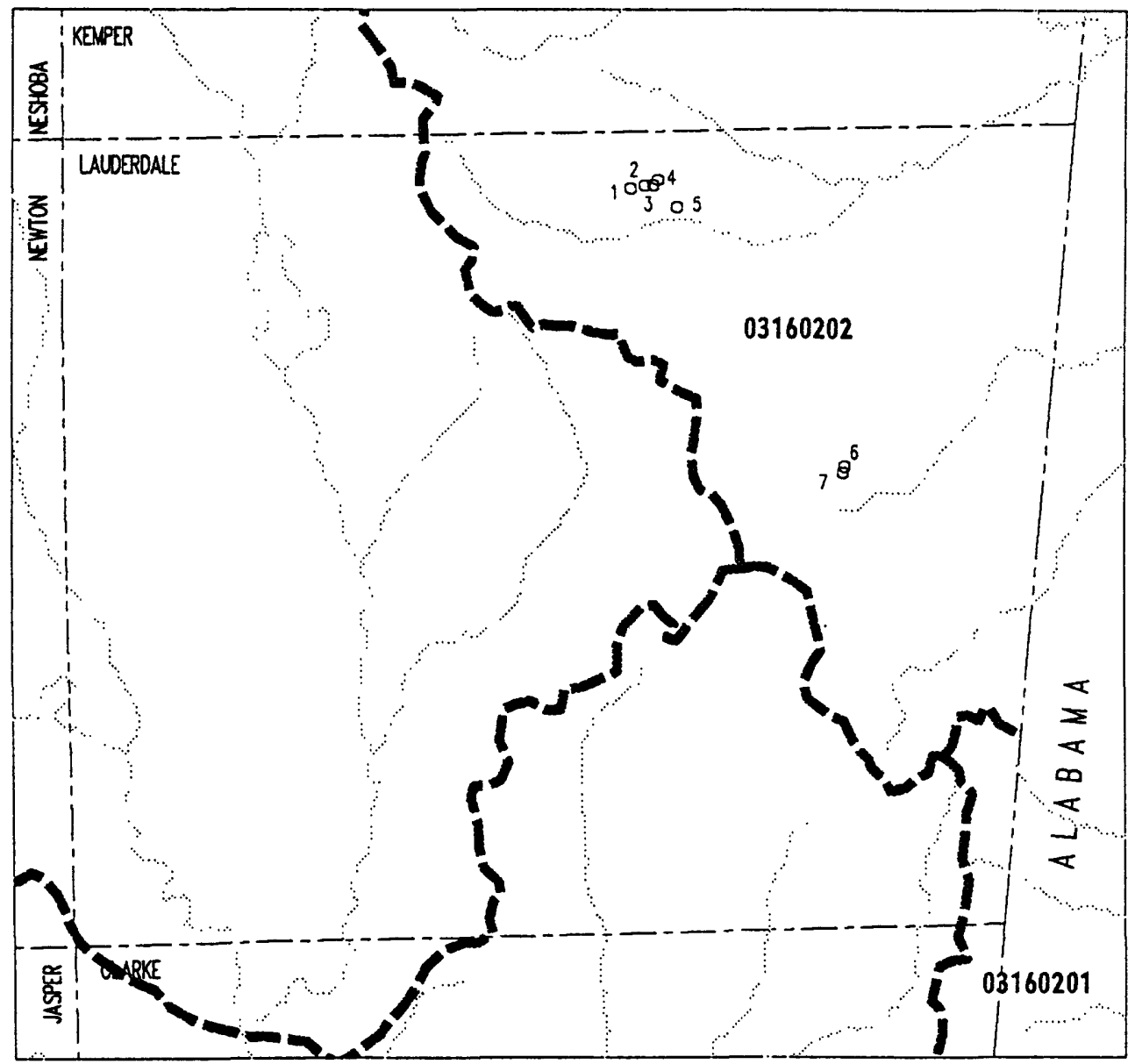

\section{EXPLANATION}

- 1 LOCATION OF PUBLIC-SUPPLY MTTHDRAYAL (NUMBERS REFEP TO TABLE 3)

HYDROLOCIC UNIT

03160101 BOUNDARY AND CODE

(CODES SHOWN FOR

BLACX FARRIOR-TOMBIGBEE BASIN ONLY)
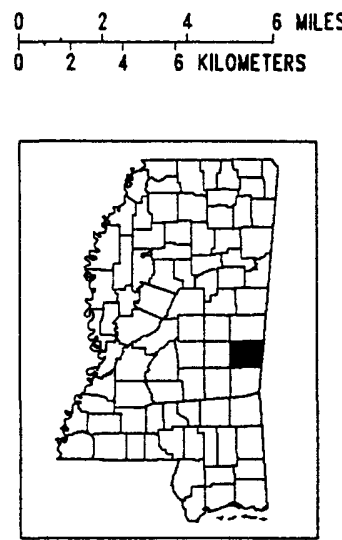

Figure 8.-Location of withdrawals for systems in Lauderdale County, Mississippi. 


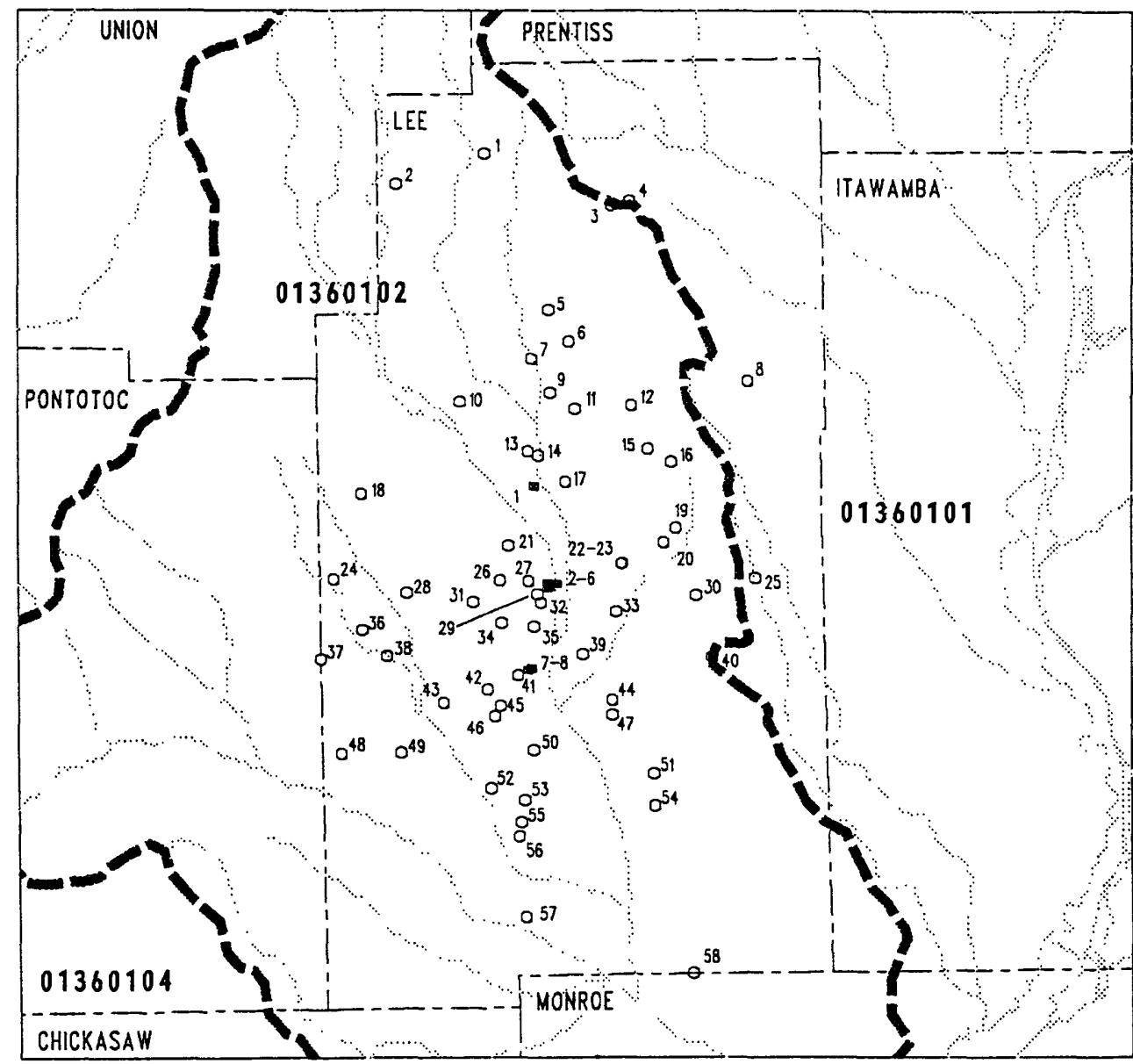

EXPLANATION

1 LOCATION OF PUBLIC-SUPPLY ITTHDRAYAL (NUMBERS REFER TO TABLE 3)

1 LOCATION OF INDUSTRIAL MITHDRA YAL (NUMBERS REFER TO TABLE 5)

- HYDROLOGIC UNIT 03160101 BOUNDARY AND CODE (CODES SHOWN FOR BLACK TARRIOR-TOMBIGBEE BASIN ONLY)

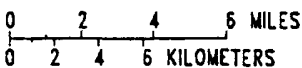

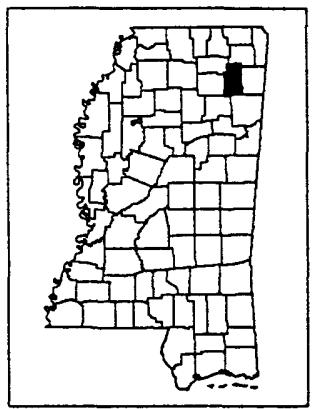

Figure 9.-Location of withdrawals for systems in Lee County, Mississippi. 


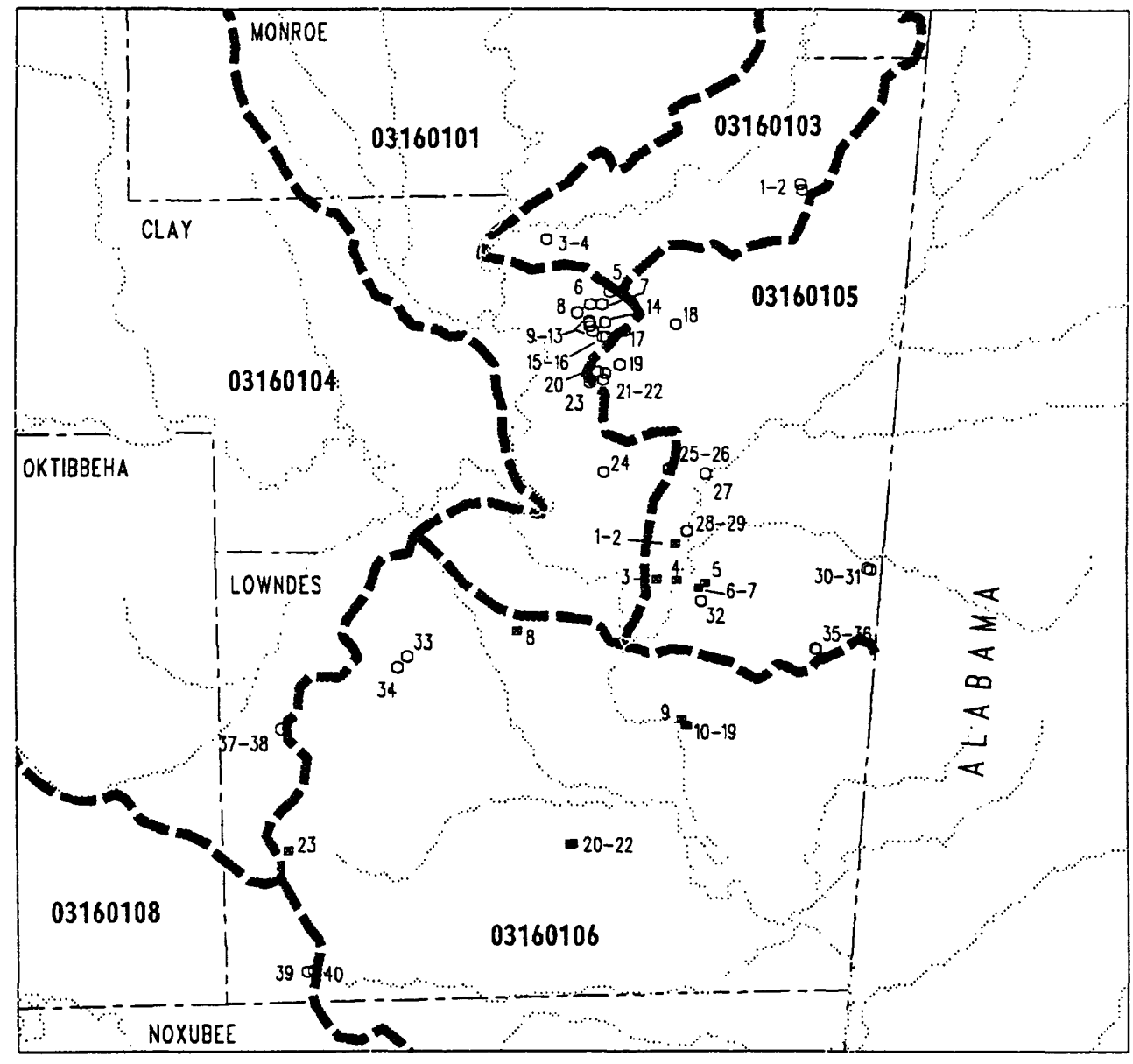

\section{EXPLANATION}

1 LOCATION OF PUBLIC-SUPPLY MTHDRAYMAL (NUMBERS REFER TO TABLE 3)

- 1 LOCATION OF INDUSTRIAL MTHDRATAL (NUMBERS REFER TO TABLE 5)

HYDROLOGIC UNIT
BouN160101
BOUNDARY AND CO (CODES SHOWN FOR BLACK TARRIOR-TOMBIGBEE BASTN ONLY)
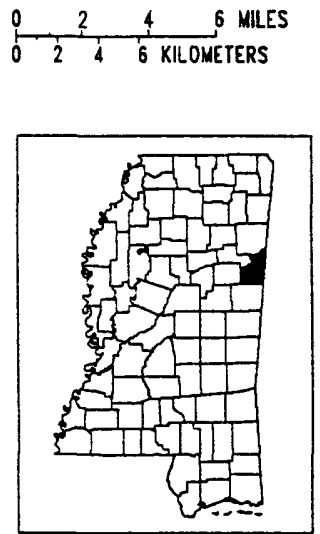

Figure 10.--Location of withdrawals for systems in Lowndes County, Mississippi. 


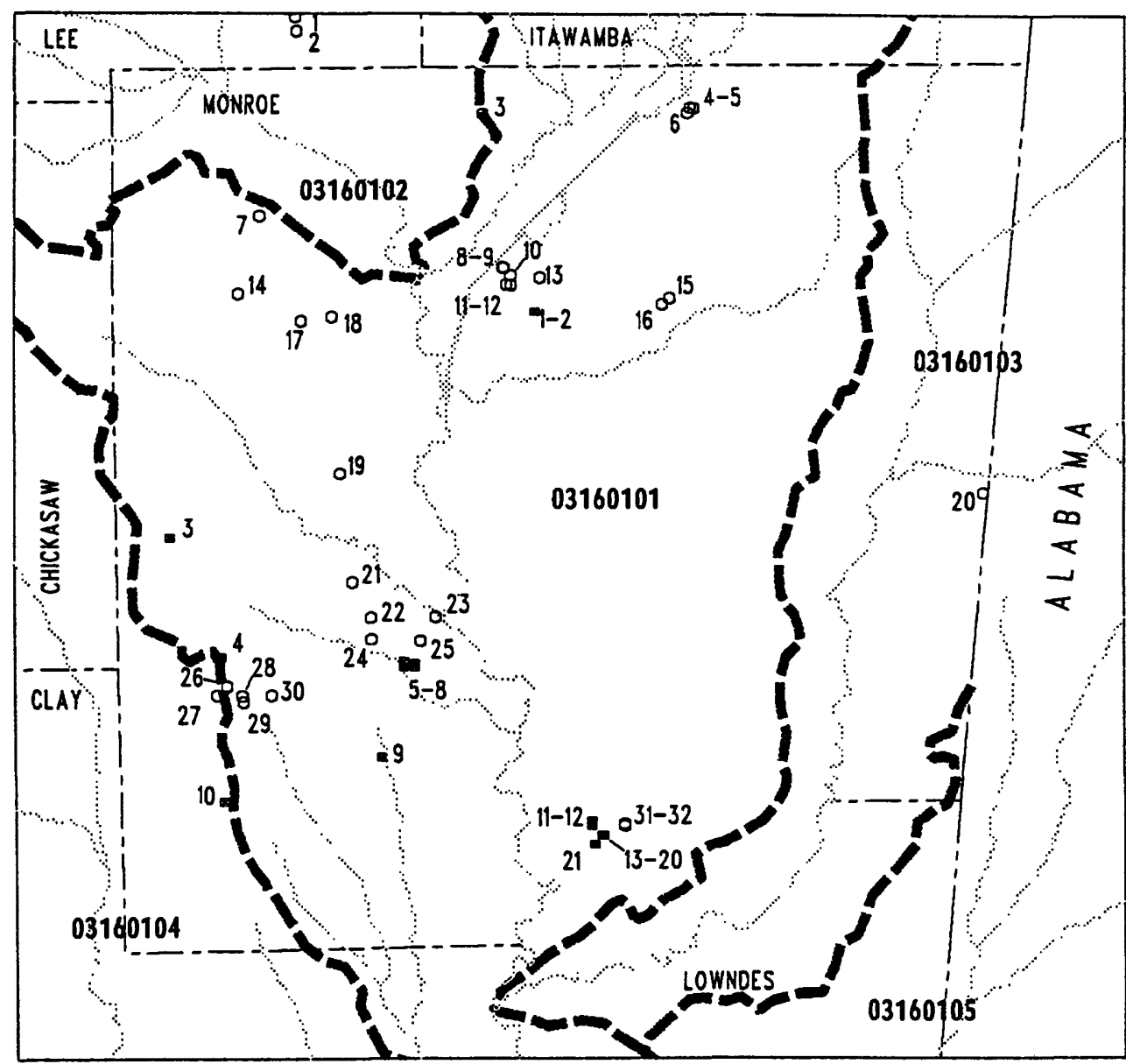

EXPLANATION

O 1 LOCATION OR PUBLIC-SUPPLY MTHDRAYAL (NUMBERS REFER TO TABLE 3)

1 LOCATTON OF INDUSTRIAL

TITHDRAYIAL (NUMBERS RERER TO TABLE 5)

HYDROLOGIC UNIT

03160101 BOUNDARY AND CODE

(CODES SHOTN POR

BLACK WARRIOR-TOMBIGBET

BASTN ONLY)
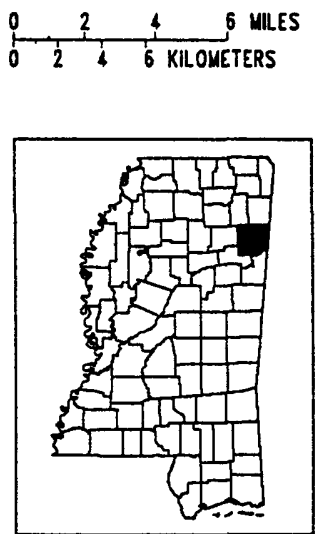

Figure 11.-Location of withdrawals for systems in Monroe County, Mississippi. 


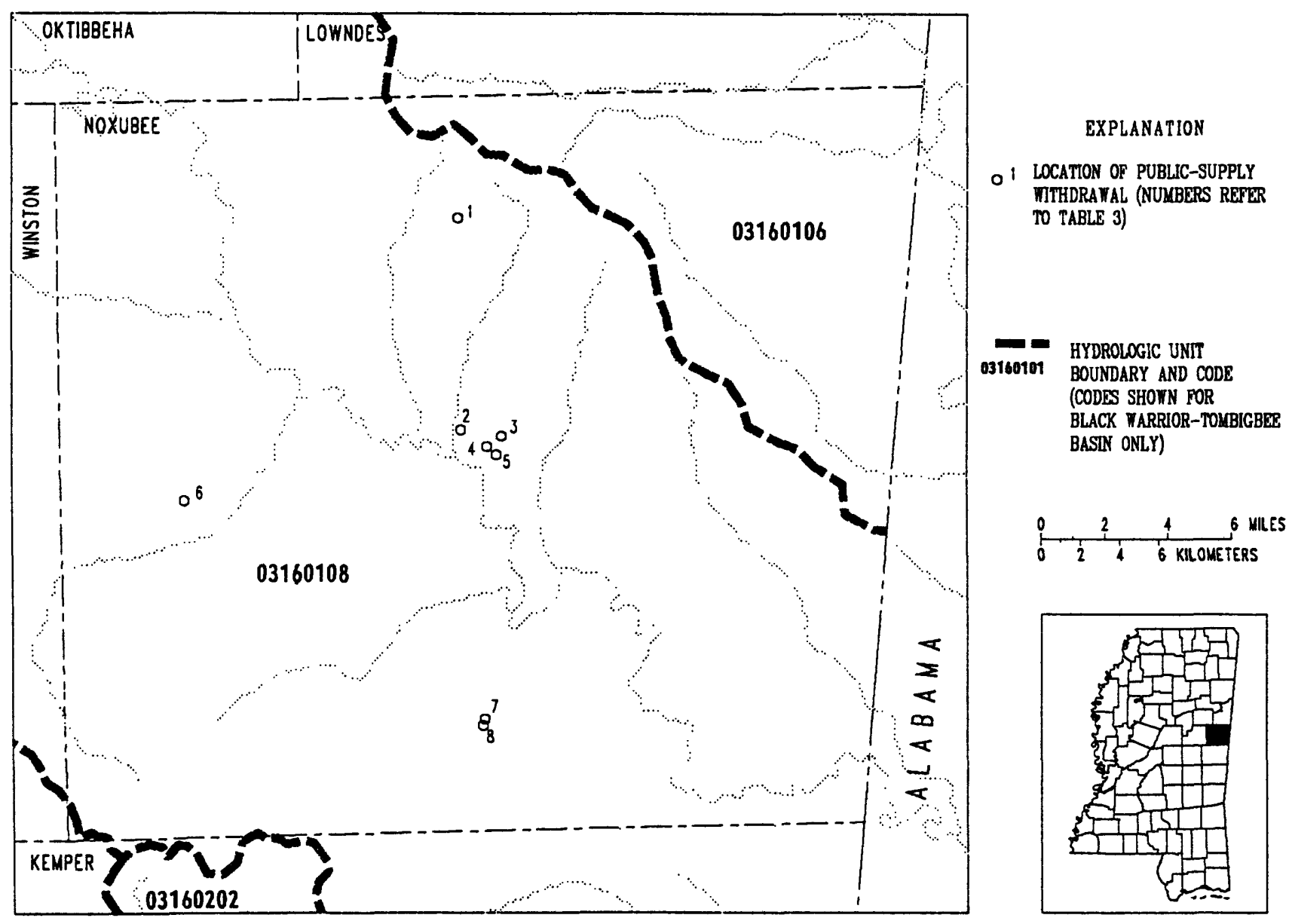

Figure 12.-Location of withdrawals for systems in Noxubee County, Mississippi. 


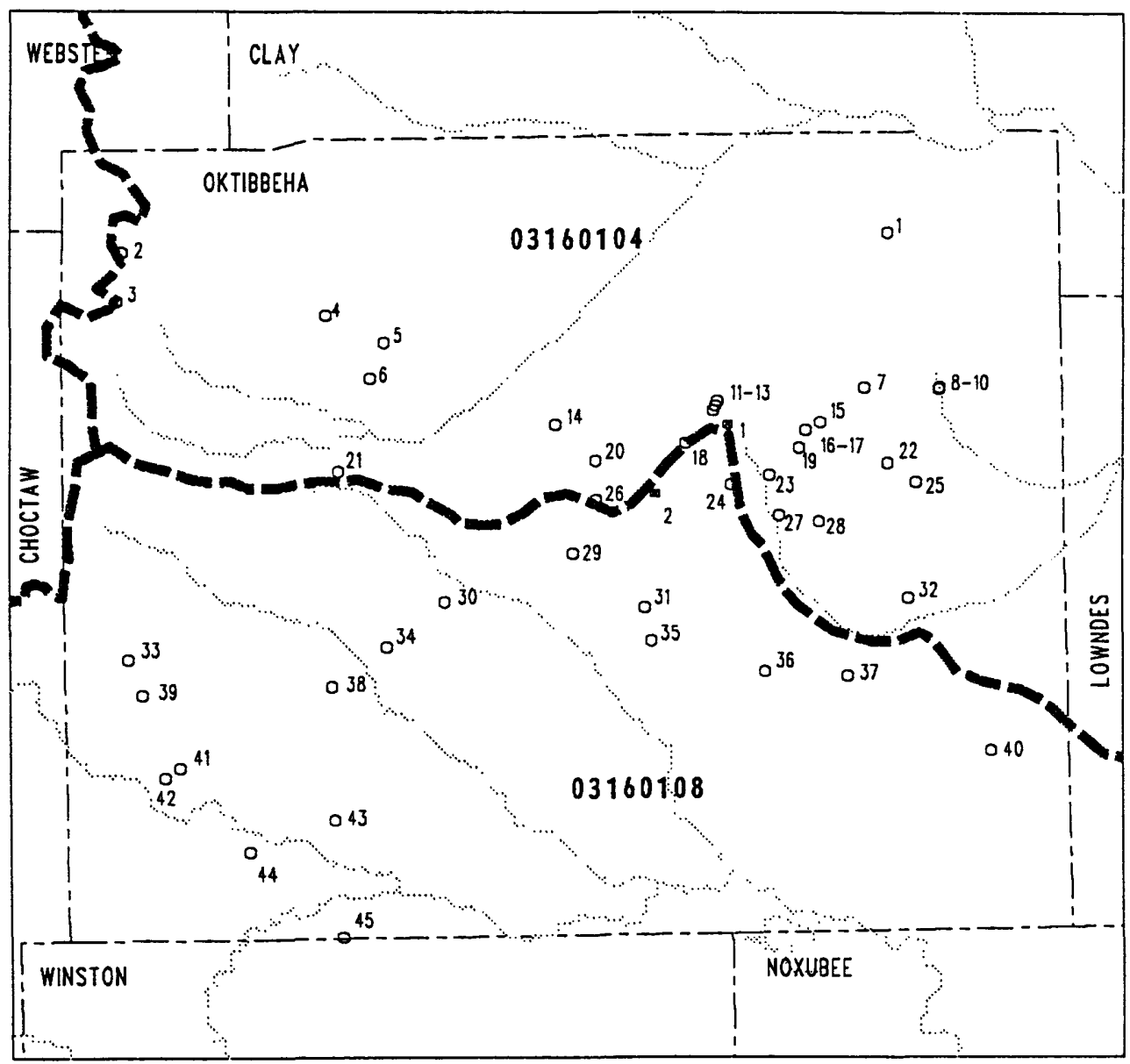

EXPLANATION

- 1 LOCATTON OR PUBLIC-SUPPLY MITHDRAWAL (NUMBERS REFER TO TABLE 3)

- 1 LOCATION OF INDUSTRIAL MTTHDRAYAL (NUMBERS REFER TO TABLE 5)

HYDROLOGIC UNIT

03160101 BOUNDARY AND CODE

(CODES SHOWN FOR

BLACK TARRIOR-TOMBIGBET BASTN ONLY)

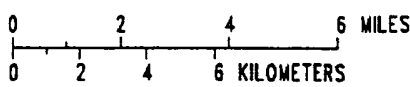

Figure 13.--Location of withdrawals for systems in Oktibbeha County, Mississippi. 


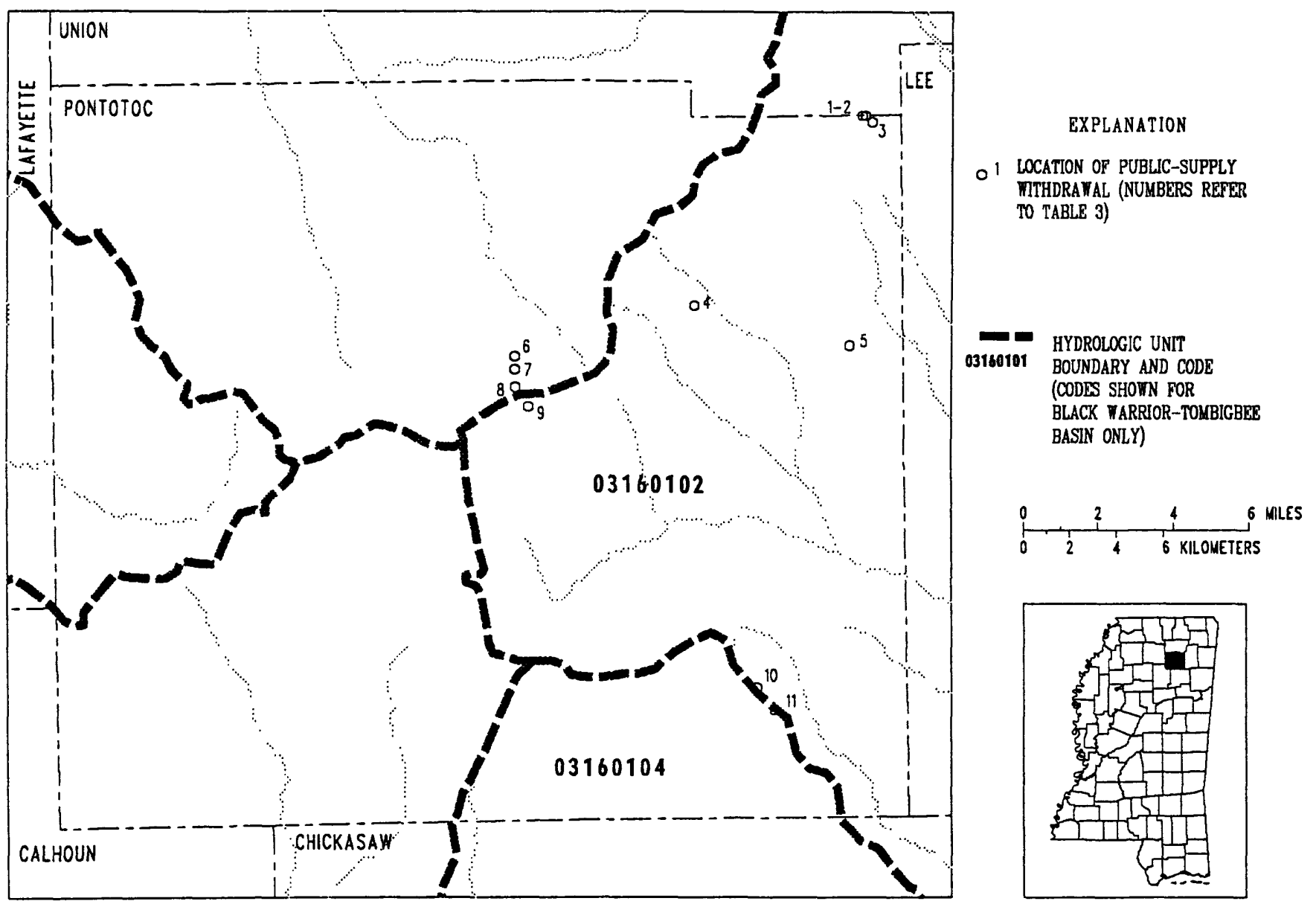

Figure 14.--Location of withdrawals for systems in Pontotoc County, Mississippi. 


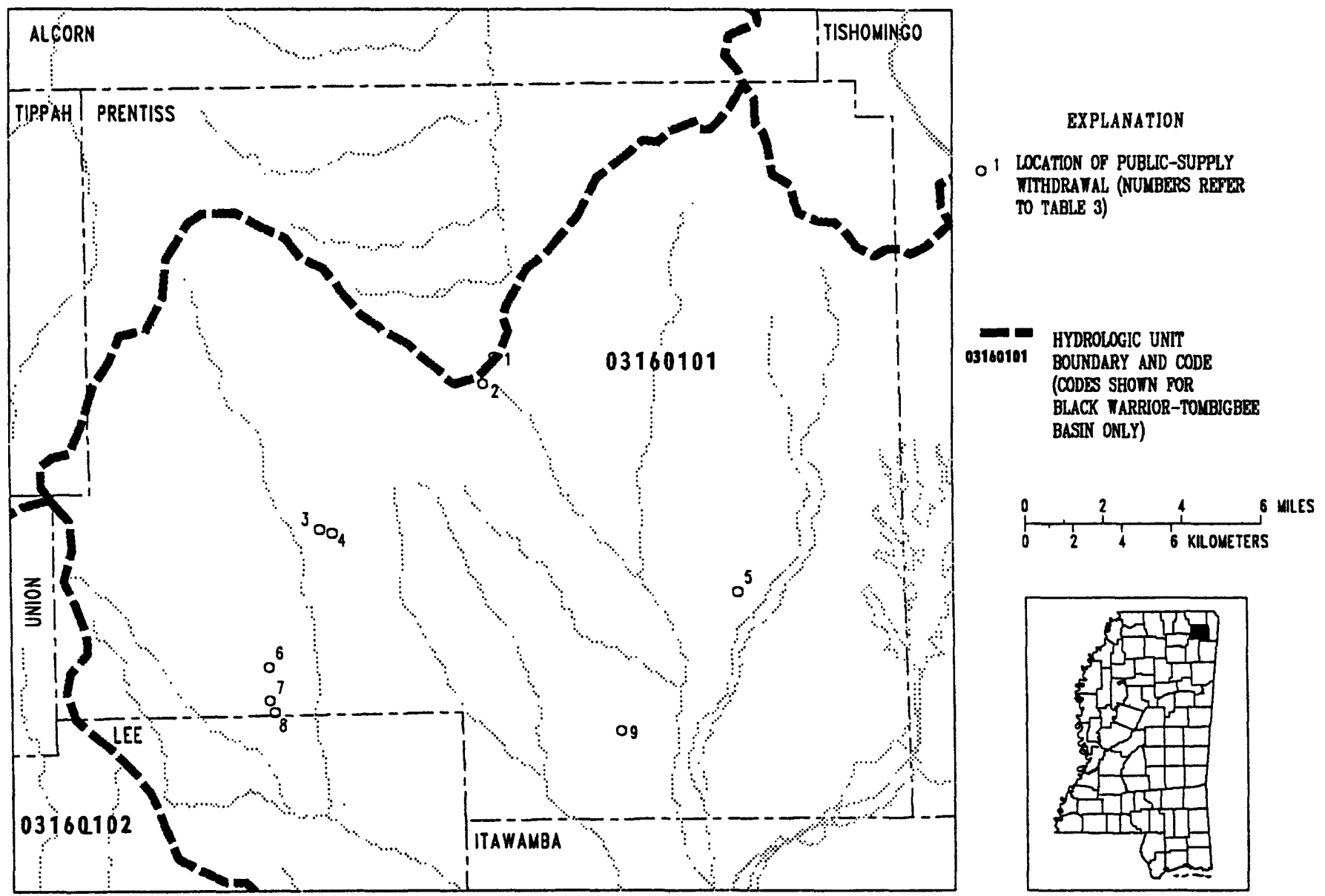

Figure 15.-Location of withdrawals for systems in Prentiss County, Mississippi. 


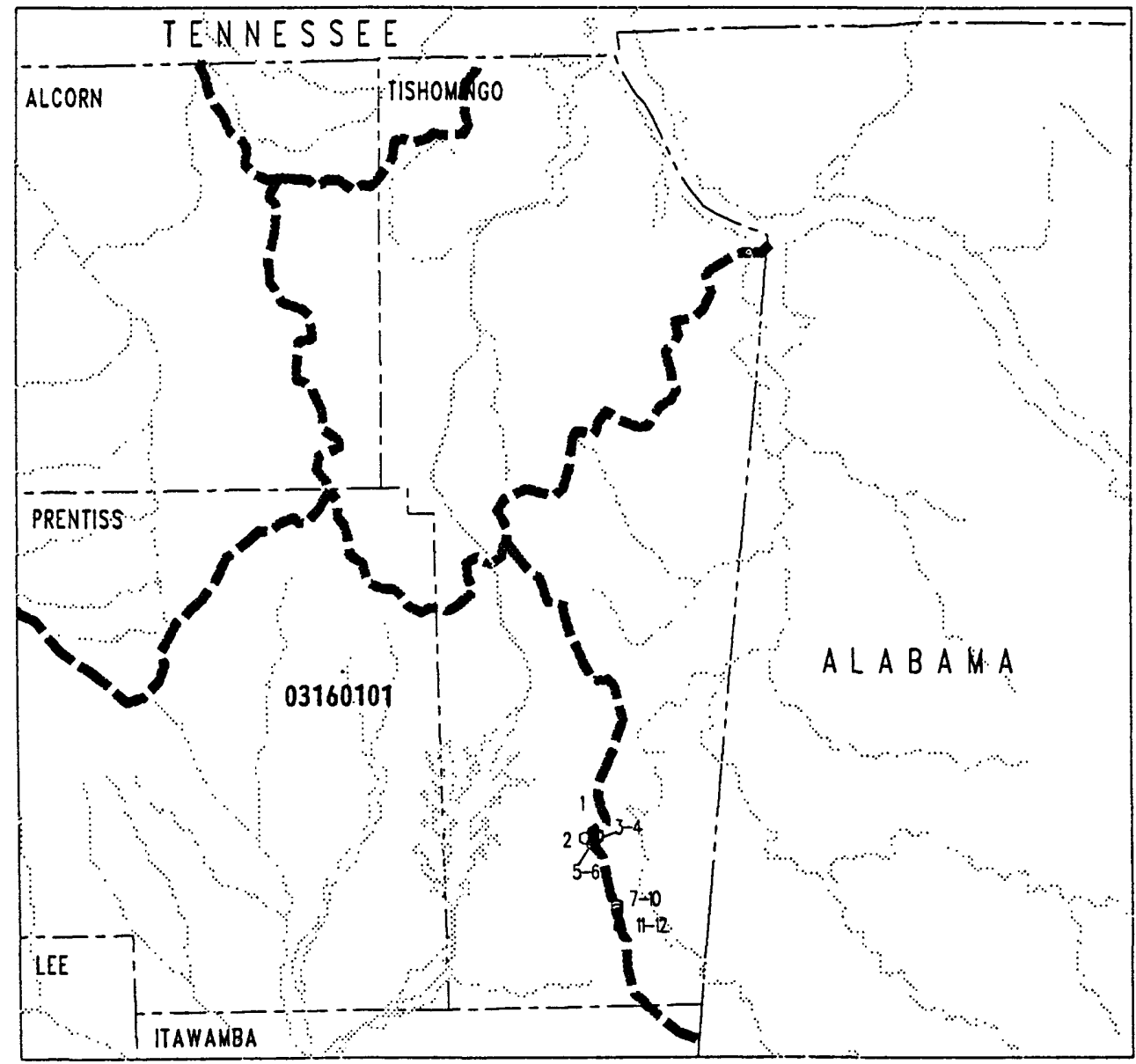

EXPLANATION

o 1 LOCATION OF PUBLIC-SUPPLY TITHDRAWAL (NUMBERS REFER TO TABLE 3)

0316010

HYDROLOGIC UNIT

BOUNDARY AND CODE

(CODES SHOWN FOR

BLACK TARRIOR-TOMBIGBEE BASIN ONLY)

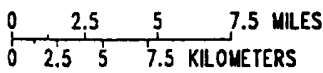

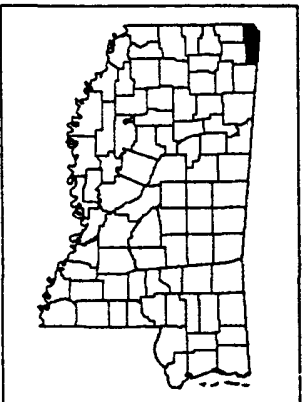

Figure 16.--Location of withdrawals for systems in Tishomingo County, Mississippi. 


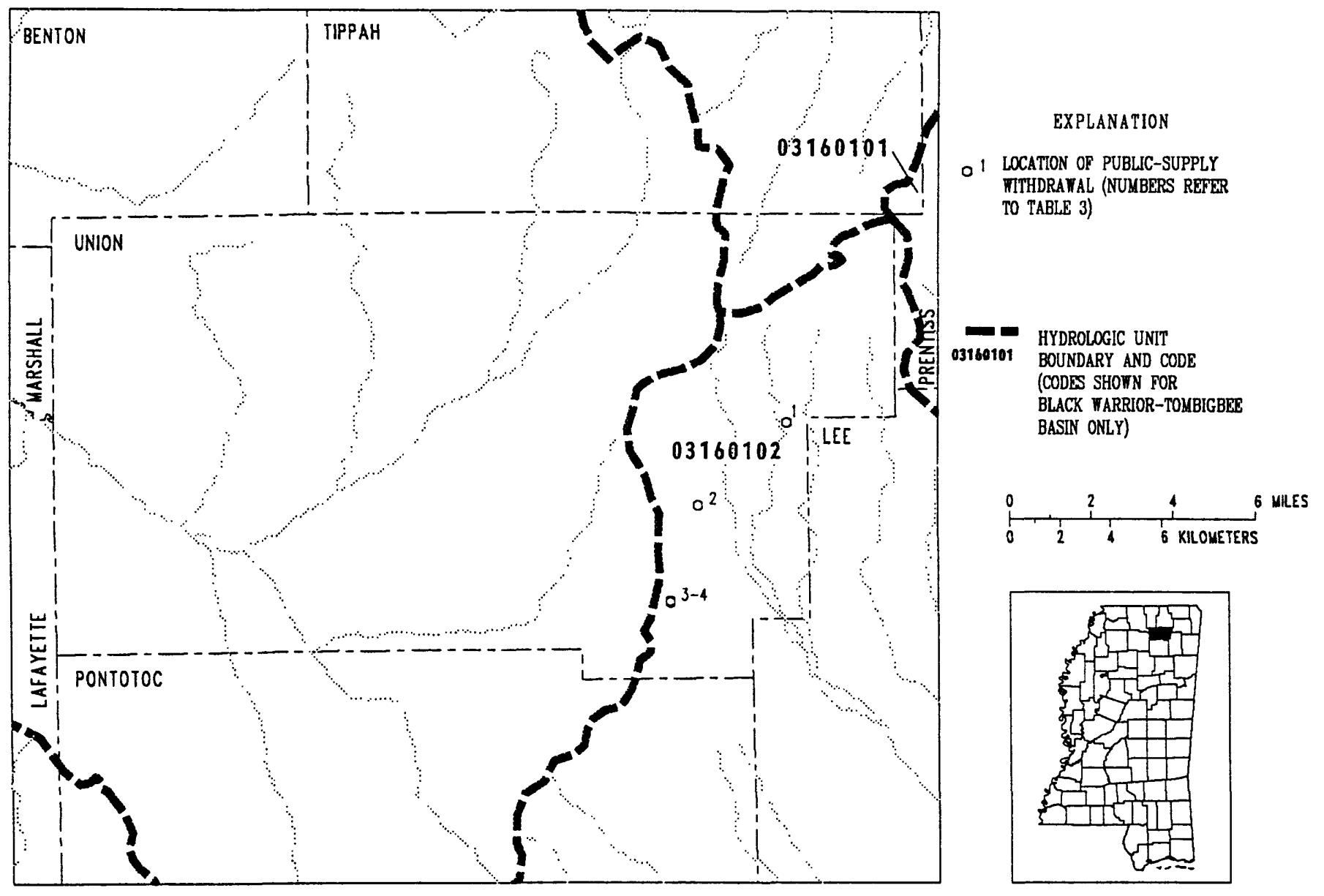

Figure 17.-Location of withdrawals for systems in Union County, Mississippi. 


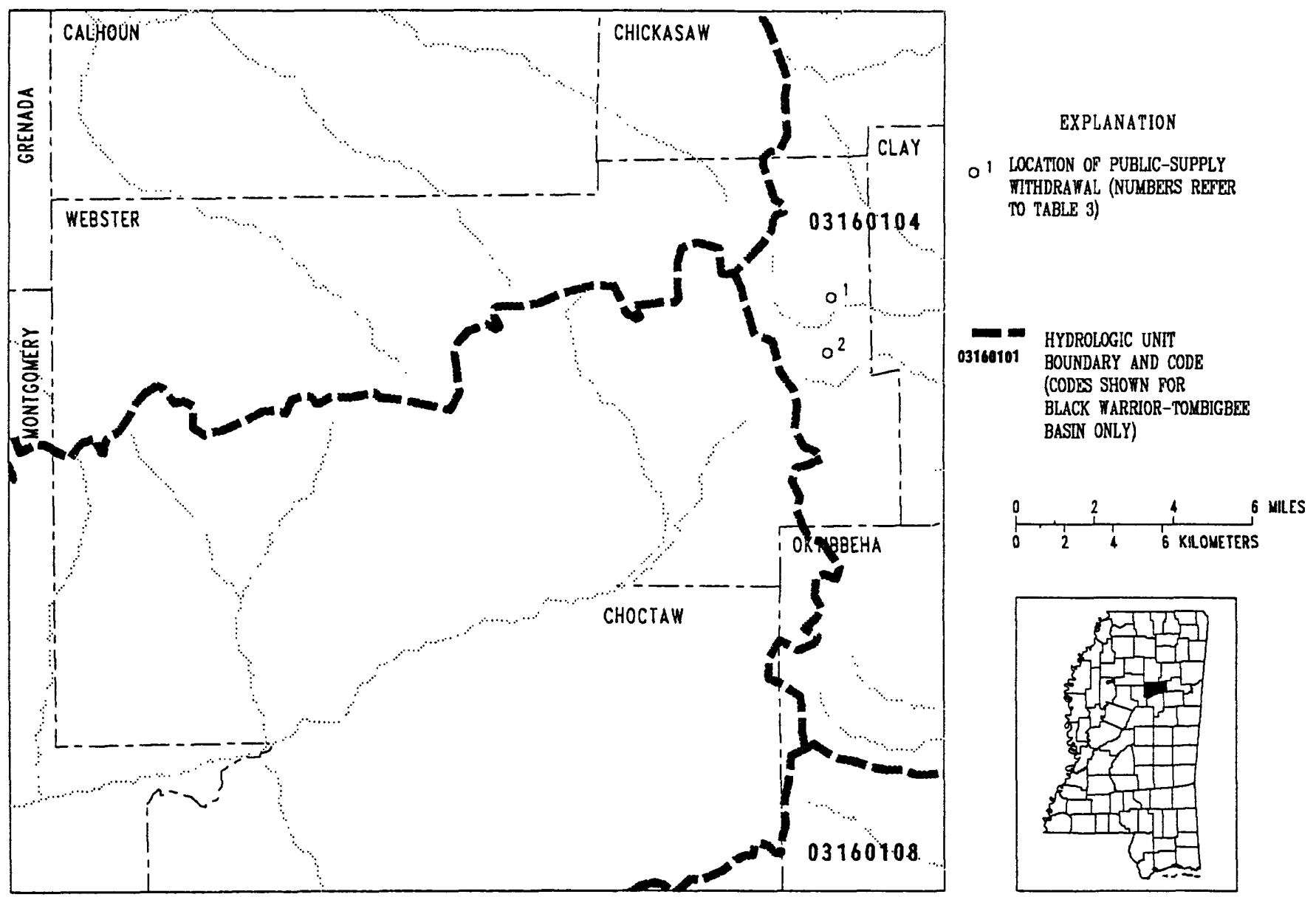

Figure 18.--Location of withdrawals for systems in Webster County, Mississippi. 


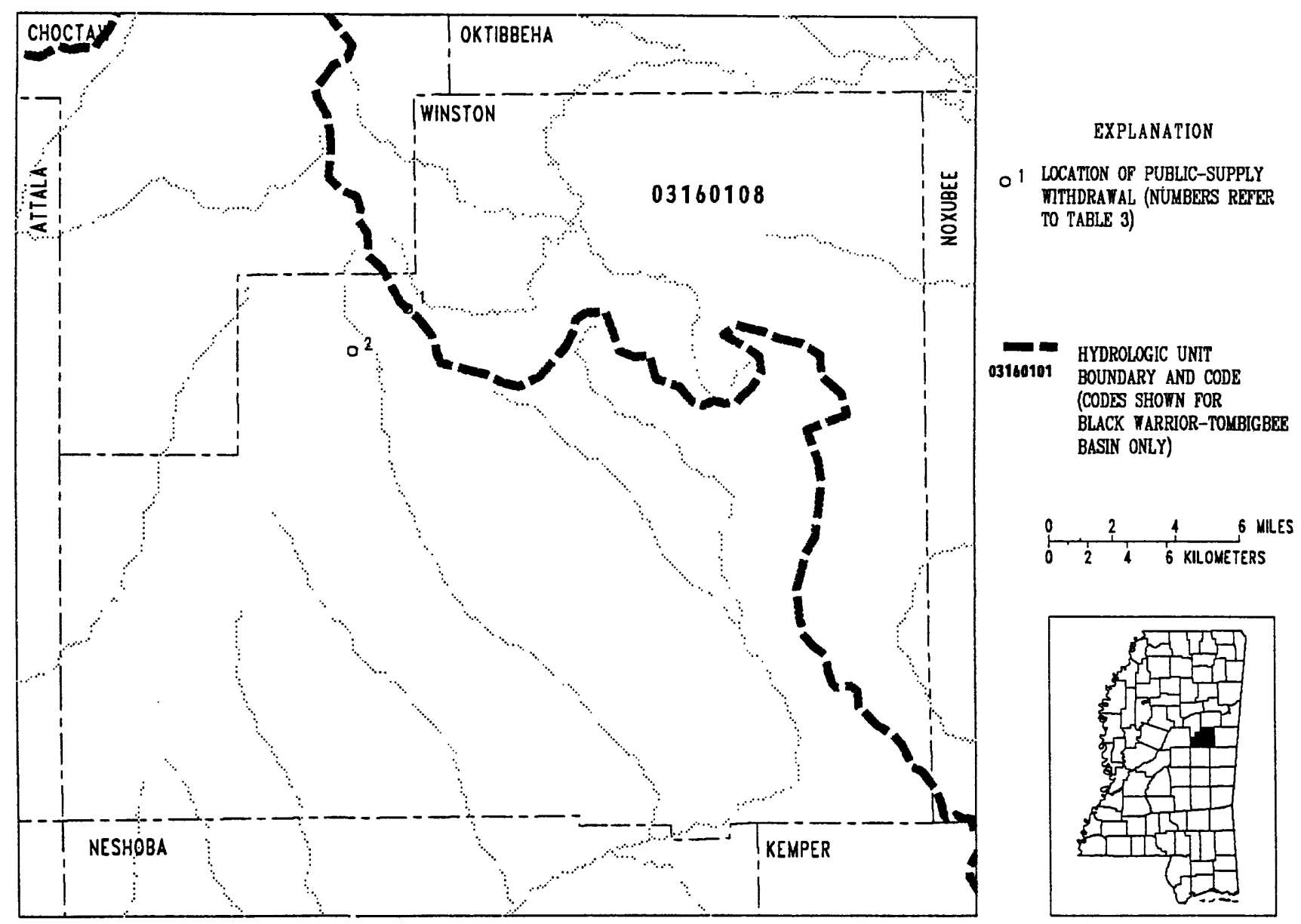

Figure 19.--Location of withdrawals for systems in Winston County, Mississippi. 
Table 1. Geologic units and principal aquifers in the study area

[Modified from Slack and Darden, 1991]

\begin{tabular}{|c|c|c|c|c|c|}
\hline Erathem & System & Series & Group & Geologic unit & $\begin{array}{l}\text { Principal aquifer } \\
\text { or aquifer system }\end{array}$ \\
\hline \multirow[t]{4}{*}{ Cenozoic } & \multirow[t]{4}{*}{ Tertiary } & \multirow[t]{2}{*}{ Eocene } & Claiborne & $\begin{array}{l}\text { Meridian Sand Member } \\
\text { and Wilcox Group, upper part }\end{array}$ & \multirow[t]{2}{*}{$\begin{array}{l}\text { Meridian-upper Wilcox } \\
\text { aquifer }\end{array}$} \\
\hline & & & & $\begin{array}{l}\text { Wilcox Group, upper part } \\
\text { Hatchetigbee Formation }\end{array}$ & \\
\hline & & \multirow[t]{2}{*}{ Paleocene } & $\begin{array}{l}\text { Wilcox } \\
\text { Group }\end{array}$ & $\begin{array}{l}\text { Tuscahoma Formation } \\
\text { Wilcox Group, middle part } \\
\text { Nanafalia Formation } \\
\text { Fearn Springs Member } \\
\text { Wilcox Group, lower part }\end{array}$ & \multirow[t]{2}{*}{ Lower Wilcox aquifer } \\
\hline & & & $\begin{array}{l}\text { Midway } \\
\text { Group }\end{array}$ & $\begin{array}{l}\text { Naheola Formation } \\
\text { Porters Creek Clay } \\
\text { Matthews Landing Marl Member } \\
\text { Clayton Formation }\end{array}$ & \\
\hline \multirow[t]{6}{*}{ Mesozoic } & \multirow{6}{*}{ Cretaceous } & \multirow{5}{*}{$\begin{array}{l}\text { Upper } \\
\text { Cretaceous }\end{array}$} & & $\begin{array}{l}\text { Prairie Bluff Chalk } \\
\text { and Owl Creek Formation }\end{array}$ & \\
\hline & & & Selma & Ripley Formation & Ripley aquifer \\
\hline & & & Group & $\begin{array}{l}\text { Demopolis Chalk } \\
\text { Coffee Sand } \\
\text { Mooreville Chalk } \\
\text { Arcola Limestone Member }\end{array}$ & Coffee Sand aquifer \\
\hline & & & $\begin{array}{l}\text { Tuscaloosa } \\
\text { Group }\end{array}$ & $\begin{array}{l}\text { Eutaw Formation } \\
\text { Tombigbee Sand Member } \\
\text { Eutaw Formation, lower part } \\
\text { McShan Formation }\end{array}$ & $\begin{array}{l}\text { Eutaw-McShan } \\
\text { aquifer }\end{array}$ \\
\hline & & & & $\begin{array}{l}\text { Gordo Formation } \\
\text { Coker Formation } \\
\text { Massive sand } \\
\end{array}$ & \multirow[t]{2}{*}{$\begin{array}{l}\text { Tuscaloosa aquifer } \\
\text { system }\end{array}$} \\
\hline & & \begin{tabular}{|l} 
Lower \\
Cretaceous
\end{tabular} & & Undifferentiated & \\
\hline Paleozoic & & & & $\begin{array}{l}\text { Undifferentiated } \\
\text { Paleozoic Erathem }\end{array}$ & $\begin{array}{l}\text { Paleozoic aquifer } \\
\text { system }\end{array}$ \\
\hline
\end{tabular}


Table 2.--Water withdrawal and risk rating for public-supplies, 1985

[Water source is aquifer unless otherwise stated; Mgal/d, million gallons per day; W A, water authority; $H$, high; $M$, moderate $L$, low; N/A, not available; dashes indicate not applicable ft/yr, foot per yearl

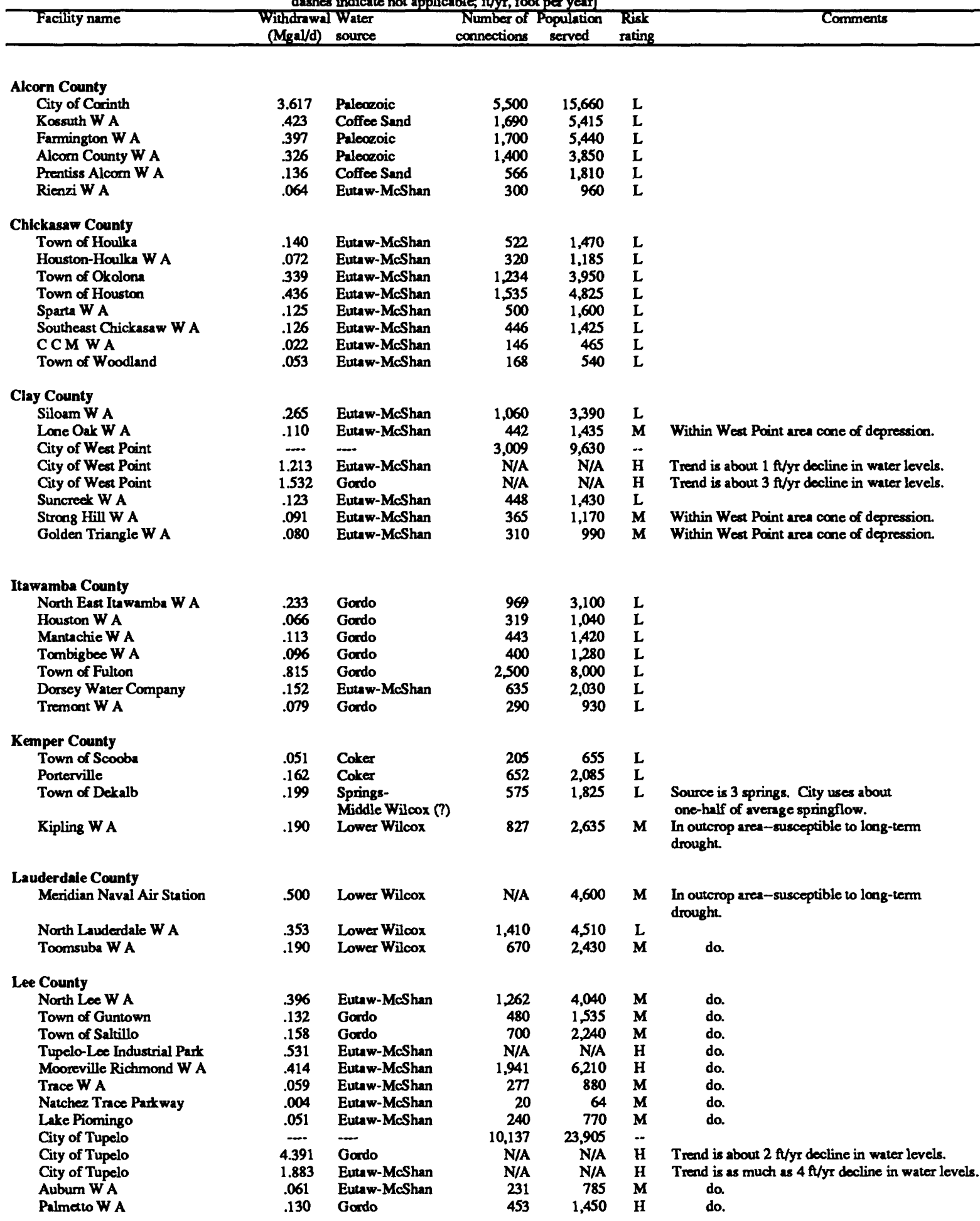




\begin{tabular}{|c|c|c|c|c|c|c|}
\hline Facility name & $\begin{array}{c}\text { Withorawal } \\
\text { (Mgal/d) }\end{array}$ & $\begin{array}{l}\text { Water } \\
\text { source }\end{array}$ & $\begin{array}{l}\text { Number of } \\
\text { connections }\end{array}$ & $\begin{array}{l}\text { Population } \\
\text { served }\end{array}$ & $\begin{array}{l}\text { Risk } \\
\text { rating }\end{array}$ & Comments \\
\hline $\begin{array}{l}\text { Lee County, cont. } \\
\text { Haven Acres Utilities } \\
\text { Town of Plantersville } \\
\text { Town of Verona } \\
\text { City Point W A } \\
\text { Town of Shannon } \\
\text { Town of Nettleton }\end{array}$ & $\begin{array}{l}0.060 \\
.113 \\
.269 \\
.128 \\
.122 \\
.230\end{array}$ & $\begin{array}{l}\text { Eutaw-MoShan } \\
\text { Eutaw-MoShan } \\
\text { Eutaw-MoShan } \\
\text { Eutaw-MoShan } \\
\text { Eutaw-MoShan } \\
\text { Eutaw-MoShan }\end{array}$ & $\begin{array}{l}310 \\
445 \\
959 \\
598 \\
379 \\
840\end{array}$ & $\begin{array}{r}990 \\
1,425 \\
3,070 \\
1,915 \\
1,030 \\
2,690\end{array}$ & $\begin{array}{l}\mathbf{M} \\
\mathbf{H} \\
\mathbf{H} \\
\mathbf{H} \\
\mathbf{H} \\
\mathbf{H}\end{array}$ & $\begin{array}{l}\text { Trend is as much as } 4 \mathrm{ft} / \mathrm{yr} \text { decline in water levels. } \\
\text { do. } \\
\text { Within Tupelo area cone of depression. } \\
\text { Within Tupelo area cone of depression. } \\
\text { do. } \\
\text { do. }\end{array}$ \\
\hline $\begin{array}{l}\text { Lowndes County } \\
\text { Town of Caledonia } \\
\text { Columbus Air Force Base } \\
\text { Airbase Trailer Park } \\
\text { Fowlkes Trailer Park } \\
\text { Parkers Mobile Home Park } \\
\text { McCarty } \\
\text { Nicholson Mobile Home Park } \\
\text { Enlow Mobile Home Park } \\
\text { Dixie Land Water Co } \\
\text { East Lowndes W A } \\
\text { City of Columbus } \\
\text { City of Columbus } \\
\text { City of Columbus } \\
\text { Pine Haven Water System } \\
\text { Golden Triangle Indust. Park } \\
\text { Town of Artesia } \\
\text { Town of Crawford }\end{array}$ & $\begin{array}{l}.194 \\
.844 \\
.015 \\
.006 \\
.031 \\
.011 \\
.006 \\
.011 \\
.071 \\
1.365 \\
.2 . \\
3.514 \\
2.004 \\
.010 \\
.022 \\
.054 \\
.051\end{array}$ & $\begin{array}{l}\text { Gordo } \\
\text { Gordo } \\
\text { Eutaw-MoShan } \\
\text { Eutaw-MoShan } \\
\text { Eutaw-MoShan } \\
\text { Eutaw-MoShan } \\
\text { Eutaw-MoShan } \\
\text { Eutaw-MeShan } \\
\text { Gordo } \\
\text { Gordo } \\
\text { Coker } \\
\text { Luxapallila Creek } \\
\text { Gordo } \\
\text { Caker } \\
\text { Gordo } \\
\text { Gordo }\end{array}$ & $\begin{array}{r}720 \\
\text { N/A } \\
190 \\
35 \\
70 \\
50 \\
42 \\
58 \\
286 \\
3,891 \\
7,798 \\
\text { N/A } \\
\text { N/A } \\
42 \\
\text { N/A } \\
215 \\
185\end{array}$ & $\begin{array}{r}2,305 \\
6,000 \\
600 \\
100 \\
225 \\
200 \\
135 \\
185 \\
915 \\
12,450 \\
28,345 \\
\text { N/A } \\
\text { N/A } \\
135 \\
\text { N/A } \\
690 \\
595\end{array}$ & $\begin{array}{l}\text { L } \\
\text { L } \\
\text { L } \\
\text { L } \\
\text { L } \\
\text { L } \\
\text { L } \\
\text { L } \\
\text { M } \\
\text { L }\end{array}$ & $\begin{array}{l}\text { Trend is less than } 1 \mathrm{ft} / \mathrm{yr} \text { decline in water levels. } \\
7 \text {-day, 10-year low flow is } 33 \mathrm{Mgal} / \mathrm{d} \text {. }\end{array}$ \\
\hline $\begin{array}{l}\text { Monroe County } \\
\text { Cason W A } \\
\text { Town of Smithville } \\
\text { Wren W A } \\
\text { Town of Amory } \\
\text { Town of Hatley } \\
\text { Coontail W A } \\
\text { Gattman W A } \\
\text { City of Aberdeen }\end{array}$ & $\begin{array}{l}.205 \\
.091 \\
.136 \\
1.230 \\
.090 \\
.064 \\
.068 \\
1.208\end{array}$ & $\begin{array}{l}\text { Gordo } \\
\text { Gordo } \\
\text { Eutaw-MaShan } \\
\text { Gordo } \\
\text { Gordo } \\
\text { Eutaw-MaShan } \\
\text { Gordo } \\
\text { Eutaw-MaShan } \\
\text { Gordo }\end{array}$ & $\begin{array}{r}836 \\
590 \\
547 \\
3,615 \\
360 \\
300 \\
271 \\
2,770\end{array}$ & $\begin{array}{r}2,640 \\
1,880 \\
1,750 \\
11,490 \\
1,150 \\
975 \\
850 \\
8,865 \\
\\
2,355\end{array}$ & $\begin{array}{l}\text { L } \\
\text { L } \\
\text { L } \\
\text { L } \\
\text { L } \\
\text { L } \\
\text { L } \\
\text { M }\end{array}$ & $\begin{array}{l}\text { Redistribution of pumpage away from the city center } \\
\text { has stabilized water levels in the area. }\end{array}$ \\
\hline $\begin{array}{l}\text { Noxubee County } \\
\text { Brooksville } \\
\text { Pineywoods W A } \\
\text { City of Macon } \\
\text { Mashulaville Util. Dist. } \\
\text { Town of Shuqualak }\end{array}$ & $\begin{array}{l}.312 \\
.030 \\
.763 \\
.045 \\
.115\end{array}$ & $\begin{array}{l}\text { Eutaw-MoShan } \\
\text { Coker } \\
\text { Coker } \\
\text { Coker } \\
\text { Gordo }\end{array}$ & $\begin{array}{r}118 \\
1,064 \\
157 \\
300\end{array}$ & $\begin{array}{r}1,650 \\
375 \\
3,405 \\
500 \\
963\end{array}$ & $\begin{array}{l}\text { M } \\
\mathbf{L} \\
\mathbf{L} \\
\mathbf{L} \\
\mathbf{L}\end{array}$ & $\begin{array}{l}\text { Water quality decreases rapidly to the south of the city's } \\
\text { wells (dissolved solids concentrations increase). }\end{array}$ \\
\hline $\begin{array}{l}\text { Oktibbeha County } \\
\text { Mhoon Farm W A } \\
\text { Double Springs W A } \\
\text { Center Grove W A } \\
\text { Adaton W A } \\
\text { Clayton Village W A } \\
\text { Herman Echols W A } \\
\text { City of Starkville } \\
\text { Mississippi State University } \\
\text { University Heights } \\
\text { New Light W A } \\
\text { Black Jack W A } \\
\text { Bluefield W A } \\
\text { Turkey Creek W A } \\
\text { Longview W A } \\
\text { Talking Warrior W A } \\
\text { Sessums Community Water } \\
\text { Wake Forest W A } \\
\text { Bradley W A } \\
\text { Oktoc W A } \\
\text { Chapel Hill W A } \\
\text { Town of Sturgis } \\
\text { Craig Springs W A } \\
\text { Morgan Chapel W A }\end{array}$ & $\begin{array}{l}.023 \\
.058 \\
.024 \\
.055 \\
.145 \\
.035 \\
2.909 \\
2.027 \\
.014 \\
.028 \\
.033 \\
.096 \\
.024 \\
.045 \\
.038 \\
.033 \\
.053 \\
.033 \\
.067 \\
.055 \\
.093 \\
.034 \\
.037\end{array}$ & $\begin{array}{l}\text { Gordo } \\
\text { Gordo } \\
\text { Gordo } \\
\text { Gordo } \\
\text { Gordo } \\
\text { Tuscaloosa } \\
\text { Gordo } \\
\text { Gordo } \\
\text { Gordo } \\
\text { Gordo } \\
\text { Gordo } \\
\text { Gordo } \\
\text { Gordo } \\
\text { Gordo } \\
\text { Gordo } \\
\text { Gordo } \\
\text { Gordo } \\
\text { Gordo } \\
\text { Gordo } \\
\text { Gordo } \\
\text { Gordo } \\
\text { Gordo } \\
\text { Gordo }\end{array}$ & $\begin{array}{r}93 \\
232 \\
95 \\
405 \\
580 \\
115 \\
5,950 \\
4,316 \\
56 \\
113 \\
133 \\
385 \\
96 \\
181 \\
150 \\
132 \\
213 \\
131 \\
270 \\
219 \\
279 \\
136 \\
148\end{array}$ & $\begin{array}{r}300 \\
740 \\
305 \\
1,295 \\
1,855 \\
400 \\
19,040 \\
13,810 \\
180 \\
360 \\
425 \\
1,230 \\
305 \\
580 \\
480 \\
420 \\
680 \\
420 \\
865 \\
700 \\
895 \\
435 \\
475\end{array}$ & $\begin{array}{l}\text { L } \\
\text { L } \\
\mathbf{M} \\
\mathbf{L} \\
\mathbf{M} \\
\mathbf{L} \\
\mathbf{H} \\
\mathbf{H} \\
\mathbf{L} \\
\mathbf{L} \\
\mathbf{M} \\
\mathbf{M} \\
\mathbf{L} \\
\mathbf{L} \\
\mathbf{L} \\
\mathbf{L} \\
\mathbf{L} \\
\mathbf{L} \\
\mathbf{L} \\
\mathbf{M} \\
\mathbf{L} \\
\mathbf{L} \\
\mathbf{L}\end{array}$ & $\begin{array}{l}\text { In Starkville area cone of depression. } \\
\text { do. } \\
\text { Trend is about } 3 \mathrm{ft} / \mathrm{yr} \text { decline in water levels. } \\
\text { Trend is about } 3 \mathrm{ft} / \mathrm{yr} \text { decline in water levels. } \\
\text { In Starkville area cone of depression. } \\
\text { do. }\end{array}$ \\
\hline
\end{tabular}




\begin{tabular}{|c|c|c|c|c|c|c|}
\hline Facility name & $\begin{array}{l}\text { Withdrawal } \\
\text { (Meal/d) }\end{array}$ & Water & $\begin{array}{l}\text { Number of } \\
\text { connections }\end{array}$ & $\begin{array}{l}\text { Population } \\
\text { served }\end{array}$ & Risk & Comments \\
\hline $\begin{array}{l}\text { Pontotoc County } \\
\text { Town of Shemman } \\
\text { East Pontotoc W A } \\
\text { City of Pontotoc } \\
\text { Troy W A }\end{array}$ & $\begin{array}{l}0.055 \\
.205 \\
.500 \\
.087\end{array}$ & $\begin{array}{l}\text { Eutaw-MaShan } \\
\text { Eutaw-MaShan } \\
\text { Gordo } \\
\text { Gordo }\end{array}$ & $\begin{array}{r}220 \\
805 \\
2,004 \\
348\end{array}$ & $\begin{array}{r}705 \\
2,575 \\
6,415 \\
1,115\end{array}$ & $\begin{array}{l}\mathbf{L} \\
\mathbf{M} \\
\mathbf{L} \\
\mathbf{L}\end{array}$ & Within Tupelo aren cone of depression. \\
\hline $\begin{array}{l}\text { Prenties County } \\
\text { Big V W A } \\
\text { Wheeler Frankston W A } \\
\text { New Site W A } \\
\text { City of Baldwyn } \\
\text { Mariett W A }\end{array}$ & $\begin{array}{l}.218 \\
.228 \\
.071 \\
.415 \\
.064\end{array}$ & $\begin{array}{l}\text { Gordo } \\
\text { Eutaw-MaShan } \\
\text { Gordo } \\
\text { Eutaw-MoShan } \\
\text { Eutaw-MoShan }\end{array}$ & $\begin{array}{r}750 \\
915 \\
250 \\
1,148 \\
214\end{array}$ & $\begin{array}{r}2,050 \\
2,040 \\
680 \\
3,065 \\
650\end{array}$ & $\begin{array}{l}\mathbf{L} \\
\mathbf{L} \\
\mathbf{L} \\
\mathbf{L} \\
\mathbf{L}\end{array}$ & \\
\hline $\begin{array}{l}\text { Tishomingo County } \\
\text { Dennis Paden W A } \\
\text { Town of Belmont }\end{array}$ & $\begin{array}{l}.195 \\
.201\end{array}$ & $\begin{array}{l}\text { Gordo } \\
\text { Gordo }\end{array}$ & $\begin{array}{r}1,000 \\
679\end{array}$ & $\begin{array}{l}3,200 \\
2,175\end{array}$ & $\begin{array}{l}\text { L } \\
\text { L }\end{array}$ & \\
\hline $\begin{array}{l}\text { Union County } \\
\text { Alpine W A } \\
\text { Blue Springs W A }\end{array}$ & $\begin{array}{l}.058 \\
.110\end{array}$ & $\begin{array}{l}\text { Eutaw-McShan } \\
\text { Eutaw-McShan } \\
\text { and Coffec Sand }\end{array}$ & $\begin{array}{l}233 \\
338\end{array}$ & $\begin{array}{r}750 \\
1,080\end{array}$ & $\mathbf{L}$ & \\
\hline $\begin{array}{l}\text { Webster County } \\
\text { Dancy W A } \\
\text { Town of Mantec }\end{array}$ & $\begin{array}{l}.018 \\
.042\end{array}$ & $\begin{array}{l}\text { Gordo } \\
\text { Coker }\end{array}$ & $\begin{array}{r}67 \\
147\end{array}$ & $\begin{array}{l}215 \\
470\end{array}$ & $\mathbf{L}$ & \\
\hline $\begin{array}{l}\text { Winston County } \\
\text { Highpoint W A }\end{array}$ & .075 & Lower Wilcox & 342 & 985 & $\mathbf{L}$ & \\
\hline
\end{tabular}


Table 3. -- Public-supply withdrawal locations

[Water source is aquifer unless otherwise stated; Mgal/d, million gallons per day; N/A, withdrawal for individual wells not

\begin{tabular}{|c|c|c|c|c|c|c|}
\hline $\begin{array}{l}\text { Map } \\
\text { number }\end{array}$ & Facility name & $\begin{array}{l}\text { Hydrologic } \\
\text { unit }\end{array}$ & Latitude & Longitude & $\begin{array}{l}\text { Water } \\
\text { source }\end{array}$ & $\begin{array}{r}1985 \text { withdrawal } \\
(\mathrm{Mgal} / \mathrm{d})\end{array}$ \\
\hline \multicolumn{7}{|l|}{ Alcorn County } \\
\hline 1 & City of Corinth & 08010207 & 345847 & 882906 & Paleozoic & $\mathbf{N} / \mathbf{A}$ \\
\hline 2 & Kossuth W A & 08010207 & 345653 & 884443 & Coffee Sand & $\mathbf{N} / \mathbf{A}$ \\
\hline 3 & City of Corinth & 06040001 & 345654 & 882703 & Paleceroic & N/A \\
\hline 4 & City of Corinth & 06040001 & 345657 & 882658 & Paleozoic & N/A \\
\hline 5 & City of Corinth & 08010207 & 345644 & 882922 & Paleozoic & N/A \\
\hline 6 & City of Corinth & 08010207 & 345617 & 883138 & Paleozoic & N/A \\
\hline 7 & City of Corinth & 08010207 & 345624 & 883115 & Paleozoic & N/A \\
\hline 8 & City of Corinth & 08010207 & 345624 & 883032 & Paleozoic & N/A \\
\hline 9 & City of Corinth & 08010207 & 345612 & 883045 & Paleozoic & N/A \\
\hline 10 & City of Corinth & 08010207 & 345545 & 883110 & Paleozoic & N/A \\
\hline 11 & Farmington W A & 08010207 & 345544 & 882743 & Paleozoic & N/A \\
\hline 12 & Farmington $\mathbf{W} \mathbf{A}$ & 08010207 & 345539 & 882652 & Paleozoic & $\mathbf{N} / \mathbf{A}$ \\
\hline 13 & Alcom County W A & 08010207 & 345523 & 883359 & Paleozoic & N/A \\
\hline 14 & Kossuth W A & 08010207 & 345452 & 883530 & Paleozoic & $\mathbf{N} / \mathbf{A}$ \\
\hline 15 & City of Corinth & 08010207 & 345456 & 883130 & Paleozoic & N/A \\
\hline 16 & City of Corinth & 08010207 & 345426 & 882915 & Paleozoic & N/A \\
\hline 17 & Kossuth W A & 08010207 & 345254 & 883826 & Paleozoic & $\mathbf{N} / \mathbf{A}$ \\
\hline 18 & Alcom County W A & 06030005 & 345115 & 882456 & Paleczoic & $\mathbf{N} / \mathbf{A}$ \\
\hline 19 & Alcom County W A & 06030005 & 345106 & 882441 & Paleozoic & N/A \\
\hline 20 & Alcom County W A & 08010207 & 345040 & 883335 & Paleozoic & N/A \\
\hline 21 & Prentiss Alcom W A & 08010207 & 344702 & 883919 & Coffee Sand & $\mathbf{N} / \mathbf{A}$ \\
\hline 22 & Prentiss Alcom W A & 08010207 & 344702 & 883919 & Coffee Sand & N/A \\
\hline 23 & Rienzi W A & 08010207 & 344600 & 883145 & Eutaw-McShan & $\mathbf{N} / \mathbf{A}$ \\
\hline 24 & Rienzi W A & 08010207 & 344550 & 883335 & Eutaw-McShan & $\mathbf{N} / \mathbf{A}$ \\
\hline 25 & Rienzi W A & 08010207 & 344550 & 883200 & Eutaw-McShan & N/A \\
\hline \multicolumn{7}{|c|}{ Chickasaw County } \\
\hline 1 & Town of Houlka & 03160104 & 340226 & 890129 & Eutaw-McShan & N/A \\
\hline 2 & Houston-Houlka W A & 03160104 & 340221 & 885918 & Eutaw-McShan & N/A \\
\hline 3 & Town of Houlka & 03160104 & 340213 & 890059 & Eutaw-McShan & N/A \\
\hline 4 & Town of Houlka & 03160104 & 340149 & 890134 & Eutaw-McShan & N/A \\
\hline 5 & Houston-Houlka W A & 03160104 & 340108 & 885925 & Eutaw-McShan & N/A \\
\hline 6 & Town of Okolona & 03160101 & 340022 & 884531 & Eutaw-McShan & N/A \\
\hline 7 & Town of Okolona & 03160101 & 335958 & 884501 & Eutaw-McShan & $\mathbf{N} / \mathbf{A}$ \\
\hline 8 & Houston-Houlka W A & 03160104 & 335755 & 885731 & Eutaw-McShan & N/A \\
\hline 9 & Town of Houston & 03160104 & 335418 & 890033 & Eutaw-McShan & N/A \\
\hline 10 & Town of Houston & 03160104 & 335345 & 885945 & Eutaw-McShan & $\mathbf{N} / \mathbf{A}$ \\
\hline 11 & Sparta W A & 03160104 & 335203 & 890103 & Eutaw-McShan & N/A \\
\hline 12 & Southeast Chickasaw W A & 03160104 & 335032 & 885521 & Eutaw-McShan & $\mathbf{N} / \mathbf{A}$ \\
\hline 13 & Southeast Chickasaw W A & 03160104 & 335034 & 885158 & Eutaw-McShan & N/A \\
\hline 14 & C C M W A & 03160104 & 335023 & 884350 & Eutaw-McShan & 0.022 \\
\hline 15 & Sparta W A & 03160104 & 334702 & 885752 & Eutaw-McShan & $\mathbf{N} / \mathbf{A}$ \\
\hline 16 & Town of Woodland & 03160104 & 334626 & 890239 & Eutaw-McShan & .053 \\
\hline
\end{tabular}


Table 3. -- Public-supply withdrawal locations--Continued

\begin{tabular}{|c|c|c|c|c|c|c|}
\hline $\begin{array}{l}\text { Map } \\
\text { number }\end{array}$ & Facility name & $\begin{array}{c}\text { Hydrologic } \\
\text { unit }\end{array}$ & Latibude & Langitude & $\begin{array}{l}\text { Water } \\
\text { source }\end{array}$ & $\begin{array}{r}1985 \text { withdrawa } \\
(\mathrm{Mgal} / \mathrm{d})\end{array}$ \\
\hline \multicolumn{7}{|l|}{ Clay County } \\
\hline 1 & Siloam W A & 03160104 & 334755 & 884818 & Eutaw-McShan & $\mathbf{N} / \mathbf{A}$ \\
\hline 2 & Siloam W A & 03160104 & 334253 & 890043 & Gordo & $\mathbf{N} / \mathbf{A}$ \\
\hline 3 & Siloam W A & 03160104 & 334044 & 885427 & Eutaw-McShan & $\mathbf{N} / \mathbf{A}$ \\
\hline 4 & Siloam W A & 03160104 & 333905 & 885921 & Eutaw-MoShan & N/A \\
\hline 5 & Siloam W A & 03160104 & 333818 & 884733 & Eutaw-McShan & N/A \\
\hline 6 & Siloam W A & 03160104 & 333814 & 884642 & Eutaw-MoShan & $\mathbf{N} / \mathbf{A}$ \\
\hline 7 & Lone Oak W A & 03160104 & 333726 & 884150 & Eutaw-McShan & $\mathbf{N} / \mathbf{A}$ \\
\hline 8 & City of West Point & 03160104 & 333726 & 883805 & Gordo & 0.766 \\
\hline 9 & City of West Point & 03160104 & 333709 & 883944 & Eutaw-McShan & .201 \\
\hline 10 & City of West Point & 03160104 & 333701 & 883937 & Eutaw-McShan & .111 \\
\hline 11 & City of West Point & 03160104 & 333706 & 883937 & Gardo & .766 \\
\hline 12 & City of West Point & 03160104 & 333650 & 883940 & Eutaw-McShan & .231 \\
\hline 13 & Suncreek W A & 03160104 & 333649 & 885438 & Eutaw-McShan & $\mathbf{N} / \mathbf{A}$ \\
\hline 14 & Siloam W A & 03160104 & 333628 & 884450 & Eutaw-McShan & N/A \\
\hline 15 & Lone Oak W A & 03160104 & 333628 & 884248 & Eutaw-McShan & N/A \\
\hline 16 & Strang Hill W A & 03160104 & 333629 & 883611 & Eutaw-McShan & N/A \\
\hline 17 & City of West Point & 03160104 & 333617 & 883907 & Eutaw-McShan & .185 \\
\hline 18 & City of West Point & 03160104 & 333548 & 883942 & Eutaw-MoShan & .189 \\
\hline 19 & City of West Point & 03160104 & 333534 & 883941 & Eutaw-MeShan & .295 \\
\hline 20 & Suncreek W A & 03160104 & 333525 & 890105 & Gondo & N/A \\
\hline 21 & Strang Hill W A & 03160104 & 333521 & 883626 & Eutaw-McShan & N/A \\
\hline 22 & Suncreek W A & 03160104 & 333455 & 885648 & Eutaw-MeShan & N/A \\
\hline 23 & Golden Triangle W A & 03160104 & 333139 & 883808 & Eutaw-MeShan & .080 \\
\hline \multicolumn{7}{|c|}{ Itawamba County } \\
\hline 1 & North East Itawamba W A & 03160101 & 342642 & 881041 & Gordo & $\mathbf{N} / \mathbf{A}$ \\
\hline 2 & North East Itawamba W A & 03160101 & 342633 & 881106 & Gondo & $\mathbf{N} / \mathbf{A}$ \\
\hline 3 & North East Itawamba W A & 03160101 & 342604 & 881129 & Gondo & $\mathbf{N} / \mathbf{A}$ \\
\hline 4 & Houston W A & 03160101 & 342553 & 882847 & Gordo & .066 \\
\hline 5 & North East Itawamba W A & 03160101 & 342527 & 881704 & Gordo & $\mathbf{N} / \mathbf{A}$ \\
\hline 6 & North East Itawamba W A & 03160101 & 342502 & 881726 & Gordo & $\mathbf{N} / \mathbf{A}$ \\
\hline 7 & Mantachic W A & 03160101 & 341935 & 882946 & Gondo & $\mathbf{N} / \mathbf{A}$ \\
\hline 8 & Mantachie W A & 03160101 & 341939 & 882952 & Gordo & $\mathbf{N} / \mathbf{A}$ \\
\hline 9 & Tombigbee W A & 03160101 & 341839 & 882729 & Gondo & N/A \\
\hline 10 & Tombigbee W A & 03160101 & 341843 & 882721 & Gordo & N/A \\
\hline 11 & Town of Fulton & 03160101 & 341622 & 882336 & Gondo & N/A \\
\hline 12 & Town of Fulton & 03160101 & 341622 & 882336 & Gordo & N/A \\
\hline 13 & Town of Fulton & 03160101 & 341622 & 882334 & Gardo & N/A \\
\hline 14 & Dorsey Water Company & 03160101 & 341519 & 883115 & Eutaw-McShan & N/A \\
\hline 15 & Dorsey Water Company & 03160101 & 341518 & 883054 & Gordo & N/A \\
\hline 16 & Town of Fulton & 03160101 & 341507 & 882434 & Gordo & N/A \\
\hline 17 & Tremant W A & 03160101 & 341419 & 881524 & Gordo & N/A \\
\hline 18 & Tremont W A & 03160101 & 341424 & 881528 & Gordo & $\mathbf{N} / \mathbf{A}$ \\
\hline \multicolumn{7}{|l|}{ Kemper County } \\
\hline 1 & Town of Scooba & 03160108 & 324946 & 882848 & Coker & .051 \\
\hline 2 & Porterville & 03160108 & 324950 & 882748 & Coker & $\mathbf{N} / \mathbf{A}$ \\
\hline 3 & Town of Dekalb & 03160202 & 324650 & 884001 & $\begin{array}{l}\text { Springs-Middle } \\
\text { Wilcox (?) }\end{array}$ & .199 \\
\hline 4 & Porterville & 03160108 & 324635 & 882755 & Caker & $\mathbf{N} / \mathbf{A}$ \\
\hline 5 & Kipling W A & 03160202 & 324051 & 884026 & Lower Wilcox & $\mathbf{N} / \mathbf{A}$ \\
\hline 6 & Kipling W A & 03160202 & 324028 & 884038 & Lower Wilcox & N/A \\
\hline
\end{tabular}


Table 3. -- Publlc-supply withdrawal locations--Continued

\begin{tabular}{|c|c|c|c|c|c|c|}
\hline $\begin{array}{l}\text { Map } \\
\text { number }\end{array}$ & Facility name & $\begin{array}{c}\text { Hydrologic } \\
\text { unit }\end{array}$ & Latitude & Langitude & $\begin{array}{l}\text { Water } \\
\text { source }\end{array}$ & $\begin{array}{r}985 \text { withdrawa! } \\
(\mathrm{Mgal} / \mathrm{d})\end{array}$ \\
\hline \multicolumn{7}{|c|}{ Lauderdale County } \\
\hline 1 & Meridian Naval Air Station & 03160202 & 323308 & 883710 & Lower Wilcox & $\mathbf{N} / \mathbf{A}$ \\
\hline 2 & Meridian Naval Air Station & 03160202 & 323312 & 883643 & Lower Wilcox & $\mathbf{N} / \mathbf{A}$ \\
\hline 3 & Meridian Naval Air Station & 03160202 & 323312 & 883627 & Lower Wilcox & $\mathbf{N} / \mathbf{A}$ \\
\hline 4 & Meridian Naval Air Station & 03160202 & 323321 & 883618 & Lower Wilcox & $\mathbf{N} / \mathbf{A}$ \\
\hline 5 & Meridian Naval Air Station & 03160202 & 323237 & 883544 & Lower Wilcox & N/A \\
\hline 6 & Toomsuba W A & 03160202 & 322544 & 883037 & Lower Wilcox & $\mathbf{N} / \mathbf{A}$ \\
\hline 7 & Toomsuba W A & 03160202 & 322534 & 883040 & Lower Wilcox & $\mathbf{N} / \mathbf{A}$ \\
\hline \multicolumn{7}{|l|}{ Lee County } \\
\hline 1 & North Lee W A & 03160102 & 342801 & 884348 & Eutaw-McShan & $\mathbf{N} / \mathbf{A}$ \\
\hline 2 & North Lee W A & 03160102 & 342712 & 884643 & Gondo & $\mathbf{N} / \mathbf{A}$ \\
\hline 3 & Town of Guntown & 03160102 & 342631 & 883937 & Eutaw-McShan & $\mathbf{N} / \mathbf{A}$ \\
\hline 4 & Town of Guntown & 03160101 & 342638 & 883859 & Gordo & $\mathbf{N} / \mathbf{A}$ \\
\hline 5 & Town of Saltillo & 03160102 & 342340 & 884145 & Eutaw-McShan & $\mathbf{N} / \mathbf{A}$ \\
\hline 6 & Town of Saltillo & 03160102 & 342248 & 884106 & Gordo & $\mathbf{N} / \mathbf{A}$ \\
\hline 7 & Tupelo-Lee Industrial Park & 03160102 & 342220 & 884221 & Eutaw-McShan & $\mathbf{N} / \mathbf{A}$ \\
\hline 8 & Mooreville Richmond W A & 03160101 & 342139 & 883507 & Eutaw-MoShan & N/A \\
\hline 9 & Tupelo-Lee Industrial Park & 03160102 & 342125 & 884144 & Eutaw-McShan & $\mathbf{N} / \mathbf{A}$ \\
\hline 10 & North Lee W A & 03160102 & 342112 & 884443 & Eutaw-McShan & $\mathbf{N} / \mathbf{A}$ \\
\hline 11 & North Lee W A & 03160102 & 342058 & 884055 & Eutaw-McShan & $\mathbf{N} / \mathbf{A}$ \\
\hline 12 & Trace W A & 03160102 & 342102 & 883901 & Eutaw-McShan & 0.059 \\
\hline 13 & Natchez Trace Parkway & 03160102 & 341948 & 884231 & Eutaw-McShan & $\mathbf{N} / \mathbf{A}$ \\
\hline 14 & Natchez Trace Parkway & 03160102 & 341941 & 884210 & Eutaw-McShan & $\mathbf{N} / \mathbf{A}$ \\
\hline 15 & Lake Piomingo & 03160102 & 341950 & 883830 & Eutaw-McShan & $\mathbf{N} / \mathbf{A}$ \\
\hline 16 & Lake Piomingo & 03160102 & 341928 & 883743 & Eutaw-McShan & N/A \\
\hline 17 & North Lee W A & 03160102 & 341857 & 884118 & Eutaw-McShan & N/A \\
\hline 18 & City of Tupelo & 03160102 & 341841 & 884802 & Gondo & .724 \\
\hline 19 & Aubum W A & 03160102 & 341739 & 883735 & Eutaw-McShan & $\mathbf{N} / \mathbf{A}$ \\
\hline 20 & Aubum W A & 03160102 & 341714 & 883800 & Eutaw-McShan & $\mathbf{N} / \mathbf{A}$ \\
\hline 21 & City of Tupelo & 03160102 & 341711 & 884312 & Gondo & .450 \\
\hline 22 & City of Tupelo & 03160102 & 341639 & 883927 & Gordo & .040 \\
\hline 23 & City of Tupelo & 03160102 & 341640 & 883925 & Eutaw-McShan & .040 \\
\hline 24 & City of Tupelo & 03160102 & 341620 & 884859 & Gondo & .220 \\
\hline 25 & Mooreville Richmond W A & 03160101 & 341612 & 883458 & Eutaw-McShan & $\mathbf{N} / \mathbf{A}$ \\
\hline 26 & City of Tupelo & 03160102 & 341614 & 884330 & Eutaw-McShan & .375 \\
\hline 27 & City of Tupelo & 03160102 & 341612 & 884234 & Eutaw-McShan & .225 \\
\hline 28 & City of Tupelo & 03160102 & 341555 & 884635 & Gordo & .556 \\
\hline 29 & City of Tupelo & 03160102 & 341550 & 884217 & Gardo & .110 \\
\hline 30 & Mooreville Richmond W A & 03160102 & 341546 & 883658 & Eutaw-McShan & N/A \\
\hline 31 & City of Tupelo & 03160102 & 341538 & 884424 & Eutaw-McShan & .366 \\
\hline 32 & City of Tupelo & 03160102 & 341536 & 884210 & Gordo & .103 \\
\hline 33 & City of Tupelo & 03160102 & 341519 & 883939 & Eutaw-McShan & .442 \\
\hline 34 & City of Tupelo & 03160102 & 341503 & 884327 & Gardo & .324 \\
\hline 35 & City of Tupelo & 03160102 & 341457 & 884223 & Eutaw-McShan & .056 \\
\hline 36 & City of Tupelo & 03160102 & 341454 & 884803 & Eutaw-McShan & .004 \\
\hline 37 & Palmeto W A & 03160102 & 341406 & 884926 & Eutaw-McShan & $\mathbf{N} / \mathbf{A}$ \\
\hline 38 & City of Tupelo & 03160102 & 341410 & 884715 & Eutaw-McShan & .375 \\
\hline 39 & City of Tupelo & 03160102 & 341409 & 884048 & Gardo & .566 \\
\hline 40 & Mooreville Richmond W A & 03160102 & 341402 & 883627 & Eutaw-McShan & N/A \\
\hline 41 & City of Tupelo & 03160102 & 341335 & 884257 & Gordo & .378 \\
\hline
\end{tabular}


Table 3. -- Public-supply withdrawal locations-.Continued

\begin{tabular}{|c|c|c|c|c|c|c|}
\hline $\begin{array}{l}\text { Map } \\
\text { number }\end{array}$ & Facility name & $\begin{array}{c}\text { Hydrologic } \\
\text { unit }\end{array}$ & Latitude & Longitude & $\begin{array}{l}\text { Water } \\
\text { source }\end{array}$ & $\begin{array}{r}1985 \text { withdrawal } \\
(\mathrm{Mgal} / \mathrm{d})\end{array}$ \\
\hline \multicolumn{7}{|c|}{ Lee County, continued } \\
\hline 42 & City of Tupelo & 03160102 & 341313 & 884358 & Gordo & 0.321 \\
\hline 43 & Haven Acres Utilities & 03160102 & 341252 & 884525 & Eutaw-McShan & .060 \\
\hline 44 & Town of Planters ville & 03160102 & 341252 & 883950 & Eutaw-McShan & N/A \\
\hline 45 & City of Tupelo & 03160102 & 341245 & 884333 & Gordo & .374 \\
\hline 46 & City of Tupelo & 03160102 & 341228 & 884344 & Gondo & .225 \\
\hline 47 & Town of Plantersville & 03160102 & 341228 & 883951 & Eutaw-MoShan & N/A \\
\hline 48 & Palmato W A & 03160102 & 341131 & 884849 & Eutaw-McShan & N/A \\
\hline 49 & Palmato W A & 03160102 & 341131 & 884650 & Gondo & N/A \\
\hline 50 & Town of Verona & 03160102 & 341133 & 884228 & Eutaw-McShan & $\mathbf{N} / \mathbf{A}$ \\
\hline 51 & City Point W A & 03160102 & 341051 & 883829 & Eutaw-McShan & N/A \\
\hline 52 & Town of Verona & 03160102 & 341030 & 884355 & Eutaw-MaShan & N/A \\
\hline 53 & Tupelo-Lee Industrial Park & 03160102 & 341010 & 884248 & Eutaw-MaShan & $\mathbf{N} / \mathbf{A}$ \\
\hline 54 & City Point W A & 03160102 & 340959 & 883828 & Eutaw-MoShan & $\mathbf{N} / \mathbf{A}$ \\
\hline 55 & Tupelo-Lee Industrial Park & 03160102 & 340934 & 884256 & Eutaw-McShan & $\mathbf{N} / \mathbf{A}$ \\
\hline 56 & Tupelo-Lee Industrial Park & 03160102 & 340911 & 884300 & Eutaw-McShan & N/A \\
\hline 57 & Town of Shannon & 03160102 & 340658 & 884251 & Eutaw-McShan & .122 \\
\hline 58 & Town of Nettleton & 03160102 & 340523 & 883717 & Eutaw-McShan & .230 \\
\hline \multicolumn{7}{|l|}{ Lowndes County } \\
\hline 1 & Town of Caledonia & 03160103 & 334050 & 881927 & Gordo & $\mathbf{N} / \mathbf{A}$ \\
\hline 2 & Town of Caledonia & 03160103 & 334100 & 881930 & Gordo & $\mathbf{N} / \mathbf{A}$ \\
\hline 3 & Columbus Air Force Base & 03160103 & 333930 & 882830 & Eutaw-McShan & N/A \\
\hline 4 & Columbus Air Force Base & 03160103 & 333930 & 882830 & Eutaw-MoShan & $\mathbf{N} / \mathbf{A}$ \\
\hline 5 & Columbus Air Force Base & 03160101 & 333754 & 882620 & Gondo & N/A \\
\hline 6 & Columbus Air Force Base & 03160101 & 333732 & 882700 & Gondo & $\mathbf{N} / \mathbf{A}$ \\
\hline 7 & Columbus Air Force Base & 03160101 & 333732 & 882636 & Gardo & $\mathbf{N} / \mathbf{A}$ \\
\hline 8 & Airbese Trailer Park & 03160101 & 333718 & 882728 & Eutaw-MaShan & $\mathbf{N} / \mathbf{A}$ \\
\hline 9 & Fowlkes Trailer Park & 03160101 & 333654 & 882701 & Eutaw-McShan & $\mathbf{N} / \mathbf{A}$ \\
\hline 10 & Parkers Mobile Home Park & 03160101 & 333700 & 882703 & Eutaw-McShan & $\mathbf{N} / \mathbf{A}$ \\
\hline 11 & Parkers Mobile Home Park & 03160101 & 333701 & 882702 & Eutaw-McShan & $\mathbf{N} / \mathbf{A}$ \\
\hline 12 & Parkers Mobile Home Park & 03160101 & 333702 & 882703 & Eutaw-McShan & $\mathbf{N} / \mathbf{A}$ \\
\hline 13 & Airbase Trailer Park & 03160101 & 333700 & 882630 & Eutaw-McShan & $\mathbf{N} / \mathbf{A}$ \\
\hline 14 & MoCarty & 03160101 & 333645 & 882655 & Eutaw-McShan & $\mathbf{N} / \mathbf{A}$ \\
\hline 15 & Nicholson Mobile Home Park & 03160101 & 333635 & 882627 & Eutaw-McShan & $\mathbf{N} / \mathbf{A}$ \\
\hline 16 & Nicholson Mobile Home Park & 03160101 & 333635 & 882635 & Eutaw-McShan & $\mathbf{N} / \mathbf{A}$ \\
\hline 17 & Enlow Mobile Home Park & 03160101 & 333645 & 882547 & Eutaw-McShan & $\mathbf{N} / \mathbf{A}$ \\
\hline 18 & Fowlkes Trailer Park & 03160105 & 333655 & 882400 & Eutaw-MaShan & $\mathbf{N} / \mathbf{A}$ \\
\hline 19 & Enlow Mobile Home Park & 03160105 & 333546 & 882559 & Eutaw-MoShen & $\mathbf{N} / \mathbf{A}$ \\
\hline 20 & MoCarty & 03160105 & 333533 & 882646 & Eutaw-MaShan & $\mathbf{N} / \mathbf{A}$ \\
\hline 21 & MoCarty & 03160105 & 333530 & 882630 & Eutaw-McShan & $\mathbf{N} / \mathbf{A}$ \\
\hline 22 & Airbase Trailer Padk & 03160105 & 333519 & 882635 & Eutuw-MoShan & $\mathbf{N} / \mathbf{A}$ \\
\hline 23 & Airbase Trailer Park & 03160101 & 333515 & 882703 & Eutaw-MaShan & $\mathbf{N} / \mathbf{A}$ \\
\hline 24 & Dixie Land Water Co & 03160101 & 333236 & 882638 & Gondo & .071 \\
\hline 25 & East Lowndes W A & 03160105 & 333240 & 882420 & Gordo & .288 \\
\hline 26 & East Lowndes W A & 03160105 & 333241 & 882419 & Gordo & .288 \\
\hline 27 & Enlow Mobile Home Park & 03160105 & 333231 & 882302 & Eutaw-McShan & N/A \\
\hline 28 & City of Columbus & 03160105 & 333050 & 882344 & Luxapallila Creek & 2.004 \\
\hline 29 & City of Columbus & 03160105 & 333051 & 882342 & Coker & 3.514 \\
\hline 30 & Esst Lowndes W A & 03160105 & 332937 & 881712 & Gordo & .132 \\
\hline 31 & East Lowndes W A & 03160105 & 332940 & 881720 & Gondo & .132 \\
\hline 32 & Pine Haven Water System & 03160105 & 332845 & 882315 & Gondo & .010 \\
\hline 33 & Golden Triangle Industrial Park & 03160106 & 332715 & 883337 & Coker & $\mathbf{N} / \mathbf{A}$ \\
\hline 34 & Golden Triangle Industrial Park & 03160106 & 332656 & 883358 & Coker & $\mathbf{N} / \mathbf{A}$ \\
\hline
\end{tabular}


Table 3. -- Public-supply withdrawal locations--Continued

\begin{tabular}{|c|c|c|c|c|c|c|}
\hline $\begin{array}{l}\text { Map } \\
\text { number }\end{array}$ & Facility name & $\begin{array}{l}\text { Hydrologic } \\
\text { unit }\end{array}$ & Latitude & Longitude & $\begin{array}{l}\text { Water } \\
\text { source }\end{array}$ & $\begin{array}{r}1985 \text { withdrawal } \\
(\mathrm{Mgal} / \mathrm{d})\end{array}$ \\
\hline \multicolumn{7}{|c|}{ Lowndes County, continued } \\
\hline 35 & East Lowndes W A & 03160105 & 332716 & 881912 & Gordo & 0.263 \\
\hline 36 & East Lowndes W A & 03160105 & 332718 & 881915 & Gordo & .263 \\
\hline 37 & Town of Artesia & 03160104 & 332512 & 883806 & Gordo & $\mathbf{N} / \mathbf{A}$ \\
\hline 38 & Town of Artesia & 03160104 & 332512 & 883806 & Coker & $\mathbf{N} / \mathbf{A}$ \\
\hline 39 & Town of Crawford & 03160108 & 331806 & 883722 & Gordo & N/A \\
\hline 40 & Town of Crawford & 03160108 & 331808 & 883708 & Gordo & N/A \\
\hline \multicolumn{7}{|l|}{ Monroe County } \\
\hline 1 & Cason W A & 03160102 & 340648 & 883651 & Eutaw-McShan & N/A \\
\hline 2 & Cason W A & 03160102 & 340624 & 883649 & Eutaw-McShan & N/A \\
\hline 3 & Cason W A & 03160102 & 340402 & 883038 & Gordo & N/A \\
\hline 4 & Town of Smithville & 03160101 & 340407 & 882335 & Gordo & $\mathbf{N} / \mathbf{A}$ \\
\hline 5 & Town of Smithville & 03160101 & 340408 & 882342 & Gordo & N/A \\
\hline 6 & Town of Smithville & 03160101 & 340359 & 882348 & Gordo & N/A \\
\hline 7 & Wren W A & 03160101 & 340115 & 883810 & Eutaw-McShan & N/A \\
\hline 8 & Town of Amory & 03160101 & 335942 & 882959 & Gordo & N/A \\
\hline 9 & Town of Amory & 03160101 & 335943 & 883002 & Gordo & N/A \\
\hline 10 & Town of Amory & 03160101 & 335930 & 882945 & Gordo & N/A \\
\hline 11 & Town of Amory & 03160101 & 335913 & 882945 & Gordo & $\mathbf{N} / \mathbf{A}$ \\
\hline 12 & Town of Amory & 03160101 & 335914 & 882954 & Gordo & $\mathbf{N} / \mathbf{A}$ \\
\hline 13 & Town of Amory & 03160101 & 335925 & 882847 & Gordo & $\mathbf{N} / \mathbf{A}$ \\
\hline 14 & Wren W A & 03160101 & 335905 & 883856 & Eutaw-McShan & N/A \\
\hline 15 & Town of Hatley & 03160101 & 335848 & 882428 & Gordo & N/A \\
\hline 16 & Town of Hatley & 03160101 & 335838 & 882443 & Gordo & N/A \\
\hline 17 & Wren W A & 03160101 & 335818 & 883649 & Eutaw-McShan & $\mathbf{N} / \mathbf{A}$ \\
\hline 18 & Wren W A & 03160101 & 335825 & 883545 & Eutaw-McShan & N/A \\
\hline 19 & Coontail W A & 03160101 & 335403 & 883536 & Eutaw-MaShan & .064 \\
\hline 20 & Gattman W A & 03160103 & 335315 & 881400 & Gordo & .068 \\
\hline 21 & City of Aberdeen & 03160101 & 335059 & 883514 & Eutaw-McShan & N/A \\
\hline 22 & City of Aberdeen & 03160101 & 335000 & 883438 & Eutaw-McShan & N/A \\
\hline 23 & City of Aberdeen & 03160101 & 335000 & 883229 & Eutaw-MaShan & N/A \\
\hline 24 & City of Aberdeen & 03160101 & 334923 & 883438 & Eutaw-MaShan & N/A \\
\hline 25 & City of Aberdeen & 03160101 & 334920 & 883300 & Eutaw-McShan & N/A \\
\hline 26 & City of Aberdeen & 03160101 & 334808 & 883932 & Eutaw-McShan & N/A \\
\hline 27 & City of Aberdeen & 03160104 & 334753 & 883952 & Eutaw-McShan & N/A \\
\hline 28 & City of Aberdeen & 03160101 & 334742 & 883859 & Eutaw-MaShan & N/A \\
\hline 29 & City of Aberdeen & 03160101 & 334752 & 883901 & Eutaw-McShan & N/A \\
\hline 30 & City of Aberdeen & 03160101 & 334753 & 883802 & Eutaw-McShan & N/A \\
\hline 31 & Hamilton W A & 03160101 & 334408 & 882620 & Gordo & N/A \\
\hline 32 & Hamilton W A & 03160101 & 334411 & 882620 & Gordo & N/A \\
\hline \multicolumn{7}{|c|}{ Noxubee County } \\
\hline 1 & Brooksville & 03160108 & 331338 & 883442 & Eutaw-McShan & .312 \\
\hline 2 & Pineywoods W A & 03160108 & 330725 & 883443 & Coker & .030 \\
\hline 3 & City of Macon & 03160108 & 330713 & 883318 & Coker & $\mathbf{N} / \mathbf{A}$ \\
\hline 4 & City of Macon & 03160108 & 330655 & 883349 & Coker & N/A \\
\hline 5 & City of Macon & 03160108 & 330640 & 883329 & Coker & N/A \\
\hline 6 & Mashulaville Util. Dist. & 03160108 & 330528 & 884430 & Coker & .045 \\
\hline 7 & Town of Shuqualak & 03160108 & 325857 & 883404 & Gordo & N/A \\
\hline 8 & Town of Shuqualak & 03160108 & 325846 & 883408 & Gordo & N/A \\
\hline
\end{tabular}


Table 3. -- Public-supply withdrawal locations--Continued

\begin{tabular}{|c|c|c|c|c|c|c|}
\hline $\begin{array}{l}\text { Map } \\
\text { number }\end{array}$ & Facility name & $\begin{array}{c}\text { Hydrologic } \\
\text { unit }\end{array}$ & Latitude & Longitude & $\begin{array}{l}\text { Water } \\
\text { source }\end{array}$ & $\begin{array}{r}1985 \text { withdrawal } \\
(\mathrm{Mgal} / \mathrm{d})\end{array}$ \\
\hline \multicolumn{7}{|c|}{ Oktibbeha County } \\
\hline 1 & Mhoon Farm W A & 03160104 & 333148 & 884436 & Gordo & 0.023 \\
\hline 2 & Double Springs W A & 03160104 & 333132 & 890352 & Gordo & N/A \\
\hline 3 & Double Springs W A & 03160104 & 333030 & 890400 & Gordo & N/A \\
\hline 4 & Center Grove W A & 03160104 & 333010 & 885845 & Gondo & .024 \\
\hline 5 & Adaton W A & 03160104 & 332935 & 885718 & Gordo & $\mathbf{N} / \mathbf{A}$ \\
\hline 6 & Adaton W A & 03160104 & 332850 & 885740 & Gordo & $\mathbf{N} / \mathbf{A}$ \\
\hline 7 & Clayton Village W A & 03160104 & 332833 & 884515 & Gondo & $\mathbf{N} / \mathbf{A}$ \\
\hline 8 & Herman Echols W A & 03160104 & 332830 & 884322 & Tuscaloosa & N/A \\
\hline 9 & Hemnan Echols W A & 03160104 & 332831 & 884321 & Eutaw-McShan & N/A \\
\hline 10 & Herman Echols W A & 03160104 & 332832 & 884321 & Gondo & $\mathbf{N} / \mathbf{A}$ \\
\hline 11 & City of Starkville & 03060104 & 332806 & 884904 & Gondo & $\mathbf{N} / \mathbf{A}$ \\
\hline 12 & City of Starkville & 03060104 & 332812 & 884901 & Gondo & N/A \\
\hline 13 & City of Starkville & 03060104 & 332818 & 884858 & Gordo & N/A \\
\hline 14 & Adaton W A & 03160104 & 332750 & 885300 & Gordo & $\mathbf{N} / \mathbf{A}$ \\
\hline 15 & Clayton Village W A & 03160104 & 332750 & 884622 & Gordo & $\mathbf{N} / \mathbf{A}$ \\
\hline 16 & Mississippi State University & 03160104 & 332740 & 884643 & Gordo & $\mathbf{N} / \mathbf{A}$ \\
\hline 17 & Mississippi State University & 03160104 & 332740 & 884643 & Gordo & $\mathbf{N} / \mathbf{A}$ \\
\hline 18 & City of Starkville & 03060104 & 332725 & 884946 & Gordo & N/A \\
\hline 19 & University Heights & 03160104 & 332718 & 884654 & Gordo & .014 \\
\hline 20 & Mississippi State University & 03160104 & 332705 & 885200 & Gordo & $\mathbf{N} / \mathbf{A}$ \\
\hline 21 & New Light W A & 03160104 & 332654 & 885829 & Gordo & $\mathbf{N} / \mathbf{A}$ \\
\hline 22 & Black Jack W A & 03160104 & 332658 & 884440 & Gordo & $\mathbf{N} / \mathbf{A}$ \\
\hline 23 & Mississippi State University & 03160104 & 332644 & 884740 & Gordo & $\mathbf{N} / \mathbf{A}$ \\
\hline 24 & City of Starkville & 03060108 & 332633 & 884838 & Gordo & $\mathbf{N} / \mathbf{A}$ \\
\hline 25 & Black Jack W A & 03160104 & 332633 & 884358 & Gordo & $\mathbf{N} / \mathbf{A}$ \\
\hline 26 & Bluefield W A & 03160104 & 332615 & 885200 & Gordo & $\mathbf{N} / \mathbf{A}$ \\
\hline 27 & Mississippi State University & 03160104 & 332554 & 884726 & Gordo & N/A \\
\hline 28 & Turkey Creek W A & 03160104 & 332545 & 884625 & Gordo & .024 \\
\hline 29 & Bluefield W A & 03160108 & 332509 & 885235 & Gordo & $\mathbf{N} / \mathbf{A}$ \\
\hline 30 & Longview W A & 03160108 & 332409 & 885550 & Gordo & .045 \\
\hline 31 & Talking Warrior W A & 03160108 & 332400 & 885050 & Gondo & $\mathbf{N} / \mathbf{A}$ \\
\hline 32 & Sessums Community Water & 03160104 & 332408 & 884411 & Gordo & .033 \\
\hline 33 & Wake Forest W A & 03160108 & 332301 & 890349 & Gordo & $\mathbf{N} / \mathbf{A}$ \\
\hline 34 & Bradley W A & 03160108 & 332313 & 885719 & Gordo & $\mathbf{N} / \mathbf{A}$ \\
\hline 35 & Talking Warrior W A & 03160108 & 332317 & 885041 & Gordo & N/A \\
\hline 36 & Oltoc W A & 03160108 & 332238 & 884750 & Gordo & $\mathbf{N} / \mathbf{A}$ \\
\hline 37 & Oktoc W A & 03160108 & 332231 & 884545 & Gordo & $\mathbf{N} / \mathbf{A}$ \\
\hline 38 & Bradley W A & 03160108 & 332225 & 885842 & Gordo & $\mathbf{N} / \mathbf{A}$ \\
\hline 39 & Wake Forest W A & 03160108 & 332216 & 890329 & Gordo & $\mathbf{N} / \mathbf{A}$ \\
\hline 40 & Chapel Hill W A & 03160108 & 332056 & 884211 & Gordo & .055 \\
\hline 41 & Town of Sturgis & 03160108 & 332045 & 890233 & Gordo & $\mathbf{N} / \mathbf{A}$ \\
\hline 42 & Town of Sturgis & 03160108 & 332034 & 890256 & Gondo & $\mathbf{N} / \mathbf{A}$ \\
\hline 43 & Craig Springs W A & 03160108 & 331939 & 885841 & Gondo & .034 \\
\hline 44 & Morgan Chapel W A & 03160108 & 331900 & 890050 & Gondo & $\mathbf{N} / \mathbf{A}$ \\
\hline 45 & Morgan Chapel W A & 03160108 & 331711 & 885832 & Gordo & $\mathbf{N} / \mathbf{A}$ \\
\hline
\end{tabular}


Table 3. -- Public-supply withdrawal locations--Continued

\begin{tabular}{cl}
\hline $\begin{array}{c}\text { Map } \\
\text { number }\end{array}$ & Facility name \\
\hline Pontotoc County & \\
1 & Town of Sherman \\
2 & Town of Sherman \\
3 & Town of Sherman \\
4 & East Pontotoc W A \\
5 & East Pontotoc W A \\
6 & Pontotoc \\
7 & Pontotoc \\
8 & Pontotoc \\
9 & Pontotoc \\
10 & Troy W A \\
11 & Troy W A
\end{tabular}

Hydrologic Latitude Longitude Water

source

1985 withdrawa

unit (Mgal/d)

Prentiss County

$\begin{array}{ll}1 & \text { Big V W A } \\ 2 & \text { Big V W A } \\ 3 & \text { Wheeler Frankston W A } \\ 4 & \text { Wheeler Frankston W A } \\ 5 & \text { New Site W A } \\ 6 & \text { City of Baldwyn } \\ 7 & \text { City of Baldwyn } \\ 8 & \text { City of Baldwyn } \\ 9 & \text { Mariette W A }\end{array}$

$\begin{array}{ll}03160102 & 342152 \\ 03160102 & 342152 \\ 03160102 & 342142 \\ 03160102 & 341710 \\ 03160102 & 341609 \\ 08030201 & 341558 \\ 08030201 & 341539 \\ 08030201 & 341513 \\ 03160102 & 341444 \\ 03160102 & 340746 \\ 03160102 & 340712\end{array}$

885029 Gordo

885035 Eutaw-McShan

885018 Eutaw-McShan

885538 Eutaw-McShan

885102 Eutaw-McShan

890101 Gordo

890101 Gordo

890100 Gordo

890037 Gordo

885354 Gardo

885323 Eutaw-McShan

N/A

N/A

N/A

N/A

N/A

N/A

N/A

N/A

N/A

N/A

N/A

$\begin{array}{rrrlr}08010207 & 343852 & 883123 & \text { Gordo } & \text { N/A } \\ 03160101 & 343814 & 883143 & \text { Eutaw-McShan } & \text { N/A } \\ 03160101 & 343451 & 883629 & \text { Eutaw-McShan } & \text { N/A } \\ 03160101 & 343446 & 883608 & \text { Eutaw-McShan } & \text { N/A } \\ 03160101 & 343313 & 882434 & \text { Gordo } & 0.071 \\ 03160101 & 343139 & 883801 & \text { Eutaw-McShan } & \text { N/A } \\ 03160101 & 343052 & 883802 & \text { Eutaw-McShan } & \text { N/A } \\ 03160101 & 343035 & 883754 & \text { Eutaw-McShan } & \text { N/A } \\ 03160101 & 343000 & 882800 & \text { Eutaw-McShan } & .064\end{array}$

Tishomingo County

$\begin{array}{cl}1 & \text { Dennis Paden W A } \\ 2 & \text { Dennis Paden W A } \\ 3 & \text { Dennis Paden W A } \\ 4 & \text { Dennis Paden W A } \\ 5 & \text { Dennis Paden W A } \\ 6 & \text { Dennis Paden W A } \\ 7 & \text { Town of Belmont } \\ 8 & \text { Town of Belmont } \\ 9 & \text { Town of Belmont } \\ 10 & \text { Town of Belmont } \\ 11 & \text { Town of Belmont } \\ 12 & \text { Town of Belmont }\end{array}$

$03160101 \quad 343340$

881342 Gordo

$03160101 \quad 343328 \quad 881402$ Gordo

$06030006 \quad 343330 \quad 881330$ Gardo

$06030006 \quad 343334 \quad 881331$ Gordo

$03160101 \quad 343316 \quad 881344$ Gordo

$03160101343322 \quad 881341$ Gordo

$06030006 \quad 343103 \quad 881248$ Gordo

$06030006 \quad 343111 \quad 881249$ Gardo

$\begin{array}{lllll}06030006 & 343112 & 881248 & \text { Gordo }\end{array}$

$06030006 \quad 343112 \quad 881249$ Gardo

$03160101 \quad 343030 \quad 881244$ Gordo

$03160101 \quad 343031 \quad 881244$ Gordo

$$
\begin{aligned}
& \text { N/A } \\
& \text { N/A } \\
& \text { N/A } \\
& \text { N/A } \\
& \text { N/A } \\
& \text { N/A } \\
& \text { N/A } \\
& \text { N/A } \\
& \text { N/A } \\
& \text { N/A } \\
& \text { N/A } \\
& \text { N/A }
\end{aligned}
$$

Union County

$\begin{array}{ll}1 & \text { Alpine W A } \\ 2 & \text { Blue Springs W A } \\ 3 & \text { Blue Springs W A } \\ 4 & \text { Blue Springs W A }\end{array}$

$03160102 \quad 342931$

$03160102 \quad 342702$

$03160102 \quad 342409$

884804 Eutaw-MaShan

885120 Eutaw-McShan

885225 Eutaw-MaShan

885225 Coffee Sand

.058

N/A

N/A

N/A

Webster County

$$
\begin{array}{ll}
1 & \text { Dancy W A } \\
2 & \text { Mantee W A }
\end{array}
$$

$03160104 \quad 334017 \quad 890327$ Gordo

.018

$03160104 \quad 333842 \quad 890336$ Coker

Winston County

1 Highpoint W A

$03160108 \quad 331051 \quad 890651$ Lower Wilcox

N/A

$03180001 \quad 330937 \quad 890848$ Lower Wilcox

N/A 
Table 4.--Water withdrawal and risk rating for seif-supplied industries

[Water source is aquifer, Mgal/d, million gallons per day; W A, water authority; H, high; M, moderate; L, low; N/A, not available; deshes indicate not applicable;

\begin{tabular}{|c|c|c|c|c|c|c|c|}
\hline $\begin{array}{l}\text { Standard Industrial } \\
\text { Classification (SIC) } \\
\text { category }\end{array}$ & $\begin{array}{l}\text { With- } \\
\text { drawal } \\
\text { (Mgal/d) }\end{array}$ & $\begin{array}{c}\text { Year } \\
\text { of } \\
\text { data }\end{array}$ & $\begin{array}{l}\text { Water } \\
\text { source }\end{array}$ & $\begin{array}{l}\text { Number of } \\
\text { employees }\end{array}$ & $\begin{array}{l}\text { SIC } \\
\text { code }\end{array}$ & $\begin{array}{l}\text { Risk } \\
\text { rating }\end{array}$ & Comments \\
\hline \multicolumn{8}{|l|}{ Clay County } \\
\hline Food and Kindred Products & 1.800 & 1985 & $\begin{array}{l}\text { Gordo and } \\
\text { Eutaw-McShan }\end{array}$ & 1,646 & 2011 & $\mathbf{M}-\mathbf{H}$ & $\begin{array}{l}\text { Trend in Gordo watere levels is about } 3 \mathrm{ft} / \mathrm{yr} \\
\text { decline: Eutaw-McShan about } 1 \mathrm{ft} / \mathrm{yr} \text { decline. }\end{array}$ \\
\hline \multicolumn{8}{|l|}{ Lee County } \\
\hline Apparel, Other Fabric Products & .006 & 1985 & Eutaw-McShan & 210 & 2321 & $\mathbf{M}$ & $\begin{array}{l}\text { Within Tupelo area cone of depression: purchases } \\
\text { some water from Tupelo. }\end{array}$ \\
\hline Food and Kindred Products & .550 & 1985 & $\begin{array}{l}\text { Gordo and } \\
\text { Eutaw-McShan }\end{array}$ & 500 & 2011 & $\mathbf{H}$ & Within Tupelo area cone of depression. \\
\hline Rubber and Misc. Plastics & .168 & 1986 & Gordo & 480 & 3011 & $\mathbf{H}$ & Within Tupelo area cone of depression. \\
\hline \multicolumn{8}{|l|}{ Lowndes County } \\
\hline Lumber and Wood Products & 1.080 & 1985 & Gordo & 530 & 2499 & $\mathbf{M}$ & $\begin{array}{l}\text { Use has not changed recently--system is not } \\
\text { metered. Within Lowndes County cone of depression. }\end{array}$ \\
\hline Apparel, Other Fabric Products & .099 & 1985 & $\begin{array}{l}\text { Gordo and } \\
\text { Eutaw-McShan }\end{array}$ & 550 & 2327 & $\mathbf{M}$ & Within Lowndes County cone of depression. \\
\hline Lumber and Wood Products & .107 & 1985 & Gordo & 225 & 2426 & $\mathbf{M}$ & $\begin{array}{l}\text { Within Lowndes County cone of depression: } \\
\text { purchases some water from Columbus. }\end{array}$ \\
\hline Food and Kindred Products & .017 & 1985 & Gordo & 130 & 2062 & $\mathbf{M}$ & Within Lowndes County cone of depression. \\
\hline Chemicals and Allied Products & 8.420 & 1987 & Coker and Gordo & 63 & 2819 & $\mathbf{M}$ & $\begin{array}{l}\text { Plant will install a cooling tower late in } 1989 . \\
\text { Pumpage in this area has declined, and water levels in the } \\
\text { Gordo have recovered } 20 \text { feet between } 1978 \text { and } 1988 \text {. A cone } \\
\text { of depression was still present in the Gordo during } 1988 \text {. }\end{array}$ \\
\hline Paper and Allied Products & 7.163 & 1988 & Coker & 430 & 2621 & $\mathbf{L}$ & $\begin{array}{l}\text { Plant does not monitor pumpage: use estimated by plant } \\
\text { engineer. }\end{array}$ \\
\hline Stone, Clay, Glass, and Concrete & .576 & 1985 & Gordo & 108 & 3241 & $\mathbf{L}$ & \\
\hline \multicolumn{8}{|l|}{ Monroe County } \\
\hline Miscellaneous Manufacturing & .401 & 1985 & Gordo & 466 & 3949 & $\mathbf{L}$ & \\
\hline Electric, Gas, and Sanitary Services & .001 & 1985 & Eutaw-MaShan & 6 & 4922 & $\mathbf{L}$ & \\
\hline Electric, Gas, and Sanitary Services & .002 & 1985 & Eutaw-MoShan & 32 & 4922 & L & \\
\hline Rubber and Misc. Plastics & .399 & 1987 & Eutaw-MoShan & 248 & 3079 & $\mathbf{M}$ & $\begin{array}{l}\text { Also purchased } 1.446 \mathrm{Mgal} / \mathrm{d} \text { from city: aquifer is thin, } \\
\text { has had moderate water-level declines. }\end{array}$ \\
\hline $\begin{array}{l}\text { Chemicals and Allied Products } \\
\text { Chemicals and Allied Products }\end{array}$ & $\begin{array}{r}<.001 \\
14.277\end{array}$ & $\begin{array}{l}1985 \\
1986\end{array}$ & $\begin{array}{l}\text { Gordo } \\
\text { Gordo }\end{array}$ & $\begin{array}{r}14 \\
350\end{array}$ & $\begin{array}{l}2899 \\
2816\end{array}$ & $\stackrel{\mathbf{L}}{\mathbf{L}-\mathbf{M}}$ & $\begin{array}{l}\text { Withdrawal rate is } 500 \text { gallons per day. } \\
\text { Continued large withdrawals may cause additional } \\
\text { water-level declines. }\end{array}$ \\
\hline \multicolumn{8}{|l|}{ Oktibbeha County } \\
\hline $\begin{array}{l}\text { Food and Kindred Products } \\
\text { Primary Metal Industries }\end{array}$ & .113 & $\begin{array}{l}1985 \\
1985\end{array}$ & $\begin{array}{l}\text { Gordo } \\
\text { Gordo }\end{array}$ & $\begin{array}{r}48 \\
250\end{array}$ & $\begin{array}{l}2023 \\
3351\end{array}$ & $\begin{array}{l}\mathbf{M} \\
\mathbf{M}\end{array}$ & $\begin{array}{l}\text { Moderate water-level doclines in this area. } \\
\text { Moderate water-level doclines in this area: installing } \\
\text { recirculation equipment (1988). }\end{array}$ \\
\hline
\end{tabular}


Table 5.--Self-supplied industrial withdrawal locations

[Water source is aquifer, $\mathrm{Mgal} / \mathrm{d}$, million gallons per day; dashes indicate not applicable; N/A, not available]

\section{Map \\ Clay County}

Map Standard Industrial

1 Food and Kindred Products

Food and Kindred Products

Food and Kindred Products

Food and Kindred Products

Lee County

Apparel, Other Fabric Products

Food and Kindred Products

Food and Kindred Products

Food and Kindred Products

Food and Kindred Products

Food and Kindred Products

Rubber and Misc. Plastics

Rubber and Misc. Plastics

Lowndes County

$\begin{array}{ll}1 & \text { Lumber and Wood Products } \\ 2 & \text { Lumber and Wood Products } \\ 3 & \text { Apparel, Other Fabric Products } \\ 4 & \text { Apparel, Other Fabric Products } \\ 5 & \text { Lumber and Wood Products } \\ 6 & \text { Lumber and Wood Products } \\ 7 & \text { Lumber and Wood Products } \\ 8 & \text { Food and Kindred Products } \\ 9 & \text { Chemicals and Allied Products } \\ 10 & \text { Chemicals and Allied Products } \\ 11 & \text { Chemicals and Allied Products } \\ 12 & \text { Chemicals and Allied Products } \\ 13 & \text { Chemicals and Allied Products } \\ 14 & \text { Chemicals and Allied Products } \\ 15 & \text { Chemicals and Allied Products } \\ 16 & \text { Chemicals and Allied Products } \\ 17 & \text { Chemicals and Allied Products } \\ 18 & \text { Chemicals and Allied Products } \\ 19 & \text { Chemicals and Allied Products } \\ 20 & \text { Paper and Allied Products } \\ 21 & \text { Paper and Allied Products } \\ 22 & \text { Paper and Allied Products } \\ 23 & \text { Stone, Clay, Glass, and Concrete }\end{array}$

Monroe County

2 Miscellaneous Manufacturing

Electric, Gas, and Sanitary Services

Electric, Gas, and Sanitary Services

Rubber and Misc. Plastics

Rubber and Misc. Plastics

Rubber and Misc. Plastics

Rubber and Misc. Plastics

Chemicals and Allied Products

Electric, Gas, and Sanitary Services

Chemicals and Allied Products

Chemicals and Allied Products

Chemicals and Allied Products

Chemicals and Allied Products

Chemicals and Allied Products

Ciiemicals and Allied Products

Chemicals and Allied Products

Chemicals and Allied Products

Chemicals and Allied Products

Chemicals and Allied Products

Chemicals and Allied Products
Hydrologic Latitude

Unit

$\begin{array}{ll}03160104 & 333516 \\ 03160104 & 333518 \\ 03160104 & 333519 \\ 03160104 & 333519\end{array}$

$\begin{array}{ll}03160102 & 341851 \\ 03160102 & 341601 \\ 03160102 & 341603 \\ 03160102 & 341608 \\ 03160102 & 341608 \\ 03160102 & 341609 \\ 03160102 & 341345 \\ 03160102 & 341347\end{array}$

03160105

03160105

03160105

03160105

03160105

03160105

03160105

03160106

03160106

03160106

03160106

03160106

03160106

03160106

03160106

03160106

03160106

03160106

03160106

03160106

03160106

03160106

03160106

03160101

03160101

03160101

03160101

03160101

03160101

03160101

03160101

03160101

03160104

03160101

03160101

03160101

03160101

03160101

03160101

03160101

03160101

03160101

03160101

03160101
333030

332927

332925

332910

332910

332919

332758

332520

332508

332508

332508

332508

332508

332508

332509

332509

332509

332509

332146

332146

332147

332142

\section{0}

335830

335218

334857

334837

334838

334844

334847

334609

334458

334410

334417

334354

334354

334354

334354

334354

334354

334354

334354

334338
333030

Longitude

Water

source

$\begin{array}{llll}883900 & \text { Gordo } & \ldots & \text { N/A } \\ 883842 & \text { Eutaw-McShan } & \ldots & \text { N/A } \\ 883843 & \text { Gordo } & -- & \text { N/A } \\ 883900 & \text { Eutaw-MaShan } & -- & \text { N/A }\end{array}$

$\begin{array}{llcr}884220 & \text { Eutaw-McShan } & 1985 & 0.006 \\ 884156 & \text { Gordo } & \ldots & \text { N/A } \\ 884152 & \text { Eutaw-McShan } & \ldots & \text { N/A } \\ 884137 & \text { Gordo } & -- & \text { N/A } \\ 884157 & \text { Gordo } & -- & \text { N/A } \\ 884156 & \text { Eutaw-McShan } & \ldots & \text { N/A } \\ 884237 & \text { Gordo } & -- & \text { N/A } \\ 884229 & \text { Gordo } & -- & \text { N/A }\end{array}$

\begin{tabular}{|c|c|c|}
\hline 882408 & Gordo & -- \\
\hline 882408 & Gordo & -- \\
\hline 882448 & Eutaw-McShan & -- \\
\hline 882406 & Gordo & -- \\
\hline 882320 & Gordo & $\cdots$ \\
\hline 882320 & Gordo & -- \\
\hline 882305 & Gordo & $\cdots$ \\
\hline 882945 & Gordo & 1985 \\
\hline 882402 & Coker & $\cdots$ \\
\hline 882353 & Gordo & $\cdots$ \\
\hline 882354 & Gordo & -- \\
\hline 882354 & Gordo & $\cdots$ \\
\hline 882354 & Gordo & -- \\
\hline 882354 & Gordo & $\cdots$ \\
\hline 882354 & Gordo & -- \\
\hline 882355 & Coker & $\cdots$ \\
\hline 882355 & Coker & $\cdots$ \\
\hline 882355 & Coker & +- \\
\hline 882355 & Coker & -- \\
\hline 882802 & Coker & -- \\
\hline 882804 & Coker & $\cdots$ \\
\hline 882758 & Coker &.- \\
\hline 883754 & Gordo & 1985 \\
\hline
\end{tabular}

882858

882858

884122

883943

883334

883312

883313

883335

883423

883942

882725

882725

882703

882703

882703

882703

882703

882703

882703

882706

882720

\section{Gordo}

Gordo

Eutaw-McShan

Eutaw-McShan

Eutaw-McShan

Eutaw-McShan

Eutaw-McShan

Gordo

Eutaw-McShan

Gordo

Gordo

Gordo

Gordo

Gordo

Gordo

Gordo

Gordo

Gordo

Gordo

Gordo
Eutaw-McShan

Year Withdrawal (Mgal/d)

N/A

N/A

N/A

N/A

N/A

V/A

N/A

N/A

N/A

.576 .

Oktibbeha County 
Table 6.--Agricuitural water withdrawals, 1985

[Note: Withdrawals are county totals and may inchude parts of the counties not within the Black Warrior-Tombigbee besin. Mgal/d, million gallons per day.]

\begin{tabular}{|c|c|c|c|c|c|c|c|}
\hline \multirow[t]{2}{*}{ County } & \multicolumn{2}{|c|}{ Total county livestock use } & \multicolumn{2}{|c|}{ Total county irrigation } & \multicolumn{2}{|c|}{ Acres ingated } & \multirow{2}{*}{$\begin{array}{l}\text { Percent of county } \\
\text { in Black Warrior- } \\
\text { Tombigbee basin }\end{array}$} \\
\hline & $\begin{array}{r}\text { Ground water } \\
\text { (Mgal/d) }\end{array}$ & $\begin{array}{r}\text { Surface water } \\
(\mathrm{Mgal} / \mathrm{d})\end{array}$ & $\begin{array}{r}\text { Ground water } \\
\text { (Mgal/d) }\end{array}$ & $\begin{array}{r}\text { Surface water } \\
(\mathrm{Mgal} / \mathrm{d})\end{array}$ & Spray & Flood & \\
\hline Alcom & 0.49 & 0.13 & 0.00 & 0.00 & 160 & 20 & 0.0 \\
\hline Chickasaw & .33 & .20 & .00 & .00 & 0 & 0 & 77.2 \\
\hline Choctaw & .18 & .09 & .00 & .00 & 0 & 20 & 16.1 \\
\hline Clarke & .09 & .09 & .00 & .00 & 0 & 0 & 5.3 \\
\hline Clay & .40 & .20 & .00 & .00 & 0 & 0 & 100.0 \\
\hline Itawamba & .41 & .08 & .00 & .08 & 0 & 350 & 99.6 \\
\hline Kemper & .08 & .12 & .00 & .00 & 0 & 0 & 82.6 \\
\hline Lauderdale & .82 & .11 & .00 & .01 & 60 & 0 & 33.0 \\
\hline Lee & .55 & .17 & .00 & .00 & 0 & 0 & 100.0 \\
\hline Lowndes & .07 & .10 & .03 & .05 & 360 & 40 & 100.0 \\
\hline Manroe & 39 & .19 & .13 & .15 & 1100 & 0 & 100.0 \\
\hline Noxubee & .63 & .21 & .20 & .10 & 1000 & 330 & 100.0 \\
\hline Oktibbeha & .09 & .14 & .07 & .00 & 300 & 0 & 99.2 \\
\hline Pontotoc & .26 & .14 & .02 & .08 & 420 & 0 & 43.6 \\
\hline Prentiss & .05 & .08 & .01 & .00 & 0 & 410 & 73.1 \\
\hline Tishomingo & .03 & .05 & .00 & .00 & 0 & 0 & 25.1 \\
\hline Union & .12 & .11 & .00 & .00 & 0 & 0 & 227 \\
\hline Webster & .09 & .06 & .00 & .12 & 150 & 400 & 10.0 \\
\hline Winston & .29 & .21 & .00 & .07 & 300 & 0 & 33.6 \\
\hline
\end{tabular}

Table 7.-Self-supplied domestic water withdrawals, 1985

[Note: Withdrawals are county totals and may include parts of the counties not within the

\begin{tabular}{|c|c|c|c|c|}
\hline County & $\begin{array}{r}\text { County po } \\
\text { Total } \\
(1,000 \text { 's })\end{array}$ & $\begin{array}{l}\text { Ilation } \\
\text { Self-supplied } \\
(1,000 \text { 's })\end{array}$ & $\begin{array}{r}\text { Self-supplied domestic } \\
\text { water use- } \\
\text { Ground water } \\
\text { (Mgal/d) }\end{array}$ & $\begin{array}{l}\text { Percent of tota } \\
\text { county population in } \\
\text { Black Warrice } \\
\text { Tombigbee basin }\end{array}$ \\
\hline Alcom & 33.00 & 1.01 & 0.05 & 0.00 \\
\hline Chicknsaw & 18.10 & .09 & .00 & 94.53 \\
\hline Choctaw & 9.00 & .17 & .01 & 8.18 \\
\hline Clarke & 17.00 & .93 & .04 & .00 \\
\hline Clay & 21.90 & 3.47 & .16 & 100.00 \\
\hline Itawambe & 20.50 & 3.74 & .17 & 100.00 \\
\hline Kemper & 10.30 & .79 & .04 & 86.19 \\
\hline Lauderdale & 78.70 & 13.17 & .59 & 10.35 \\
\hline Lee & 60.80 & 1.23 & .06 & 100.00 \\
\hline Lowndes & 59.20 & 12.32 & 56 & 100.00 \\
\hline Monmee & 36.90 & 1.63 & .07 & 100.00 \\
\hline Noxubee & 13.00 & 5.03 & .23 & 100.00 \\
\hline Oktibbeha & 36.90 & 2.91 & .12 & 98.54 \\
\hline Pontotoc & 22.00 & .83 & .04 & 51.79 \\
\hline Prentisa & 24.80 & .02 & .00 & 61.22 \\
\hline Tishomingo & 18.00 & .00 & .00 & 19.62 \\
\hline Union & 22.00 & 3.98 & .17 & 19.85 \\
\hline Webater & 10.40 & .04 & .00 & 1.53 \\
\hline Winston & 19.20 & .00 & .00 & 7.54 \\
\hline
\end{tabular}

